First draft: 8 September, 2008

Second draft: 14 October, 2008

This draft:: 8 November, 2008

\title{
FINANCIAL CRISES, SAFETY NETS AND REGULATION
}

\author{
by
}

\author{
Michele Fratianni* \\ Kelley School of Business, Indiana University \\ Department of Economics, Università Politecnica delle Marche
}

\begin{abstract}
$\underline{\text { Abstract }}$
The historical record shows that financial crises are far from being a rare a phenomenon; they occur often enough to be considered part of the workings of finance capitalism. While there is no single hypothesis that can best explain all crises, the implications of the credit boom-and-bust hypothesis, supplemented with asymmetric information, are consistent with the onset and development of many crises, including the current subprime crisis. Governments have reacted to crises by erecting a vast and growing safety net. In turn, to minimize their risk exposure, they have also put in place expansive systems of regulation and supervision. The unwinding of the current crisis will mark a big enlargement of the safety net and moral hazard, as well as a predictable flurry of policy proposals aimed at closing past regulatory loopholes. The maintained hypothesis is that regulatory and market failures are inexorably intertwined.
\end{abstract}

JEL Classification: E58, F30, G21, N20

Keywords: bailout, credit, crisis, money, moral hazard, regulation, safety net, subprime

* Invited lecture at the annual meetings of the Società Italiana degli Economisti (Perugia, 24 October, 2008). I thank Pietro Alessandrini, John Pattison, David VanHoose, and an anonymous referee for comments and suggestions on earlier drafts of the paper. 


\section{INTRODUCTION}

Financial crises are an apparent by-product of market economies and governments have responded to these crises by erecting vast and growing safety nets. In turn, to minimize their risk exposure, governments have built expansive systems of regulation and supervision. The interplay of the safety net with regulation and supervision has failed, so far, in preventing or reducing the frequency and severity of financial crises. These are the main themes of this paper. ${ }^{1}$

History is littered with bank runs, bank panics, debt crises, security crashes, and financial tsunamis. Since its beginning, banking manifested its fragility, squeezed between its commitment to honor depositors on demand and extending hard-to-liquidate loans to business and sovereigns. The bankruptcy of the Bardi and Peruzzi banks in Florence between 1343 and 1346, after Edward III of England failed to pay his debts, was so devastating at home and abroad to qualify as the first significant international debt crisis (Cipolla 1982, pp. 7-8). Fourteenth and fifteenth century Venice was plagued by an extremely high rate of bank failures, brought about by commercial failures, seasonal fluctuations in the demand for money, swings in commodity prices, famine and, naturally, bankers' incompetence and dishonesty. ${ }^{2}$ Public authorities, aware of this fragility and fearful of the consequences of bank crises, placed severe restrictions on lending and harsh penalties on defaulting bankers. In Venice, bbankers who declared bankruptcy, not only lost their wealth, but were banned from public office, if noble, or from conducting business, if non-nobles. In Catalonia, a defaulting banker could even lose his head (Usher 1943, pp. 240-42). Yet, banks kept failing and governments, at times, had no better alternative than rescue those which were too significant to fail. ${ }^{3}$

Absolutist monarchs, unconstrained by the commitment to honor promises and property rights, were also prone to default on their debts. French kings defaulted twelve times between 1559 and 1797; Spanish thirteen times between 1557 to 1696; and British twice, one in 1671 and again in 1685 (Ferguson 2001, 141-42).

\footnotetext{
${ }^{1}$ The paper does not deal with the large and growing literature on whether central banks should practice "benign neglect” with respect to asset prices or include them explicitly in their reaction functions.

${ }^{2}$ According to data compiled by Mueller (1997, chs. 4 and 5, Table B.I), 46 deposit banks failed in Venice between 1327 and 1500 .

${ }^{3}$ The Republic of Venice, as early as 1375, considered some Rialto banks public institutions and thus eligible for an ex-post safety net (i.e., public rescue); see Mueller (1997, p. 124).
} 
The English Glorious Revolution of 1688, by shifting the balance of power from the monarchy to taxempowered parliament, established a more credible commitment to honor property rights and reduced the proclivity of the state to default on its obligations (North and Weingast 1989).

Kindleberger (1978) produces a list of major financial crises from 1622 to 1998 . Adding to this list the Savings and Loan (S\&L) crisis of the United States of the 1980s, the banking crisis in Finland, Norway, and Sweden of the early 1990s, the currency crisis of Italy and the U.K. in 1992, the Argentine debt default of 200001 and the subprime crisis of 2007-2008, we arrive at the following crisis count: nine in the 1700s, 22 in the pregold standard 1800s, seven during the international gold standard (1880-1913), eight in the inter-war period (1919-1939), six during the Bretton Woods period, and 16 in the most recent period 1974-2008; see Table 1 for more details. These patterns are broadly confirmed by Bordo et al (2001) who compare frequency, duration and depth of banking and currency crises in the gold standard, interwar years, Bretton Woods period and recent period starting in 1973 and ending in $1997 .{ }^{4}$ On frequency, the recent period comes out worse than the gold standard period, better than the interwar years and worse than the Bretton Woods period. On duration of the crises, defined as the number of years it takes for GDP growth to return to trend rate, the Bretton Woods period has produced the mildest crises and the current period the worst. Finally concerning depth, defined as the cumulative loss of GDP, the interwar period is associated, not surprisingly; with the deepest crises while Bretton Woods with the mildest.

\section{[Insert Table 1 here]}

In sum, the evidence suggests that financial crises are far from being a rare a phenomenon; they occur often enough to be considered part of the workings of finance capitalism. Crises tend to erupt where banking and finance are most advanced (Reinhart and Rogoff 2008). England (later the U.K.), arguably at the frontier of international money, banking and finance since the $18^{\text {th }}$ century, has suffered 17 crises according to the

\footnotetext{
${ }^{4}$ While more restrictive in time than Kindleberger's list if crises, Bordo et al. have a broader country coverage: 21 countries for the four mentioned sub-periods and an alternative sample of 56 countries for the recent period. Furthermore, unlike Kindleberger's qualitative criterion, Bordo et al. define banking crises as events that destroy most of the banking capital and currency crises as either a forced change in parity or an international rescue.
} 
expanded Kindleberger's data. The United States, also at the frontier of money and finance at least since World War I, has suffered 14 crises, of which three massive (that of 1933, the S\&L, and the subprime). Combined, these two countries, again using the expanded Kindleberger's data, account for almost half of the crises. On the other hand, countries where finance is embryonic or catatonic, like North Korea, escape the scourge of financial crises. The frequency and duration of crises have increased with liberalization of domestic financial markets and international financial integration. According to the data compiled by Graciela Kaminsky and Carmen Reinhart (1999, Table 1), banking crises occurred at an average rate of 1.44 a year in the more open period 1980-1995, in contrast to an average rate of 0.30 a year in the less open period $1970-1979 .{ }^{5}$

The paper focuses on the historical record more than on current events because the intent is to draw lessons that are not contingent on a particular episode. Nonetheless, I will compare the long record with the ongoing subprime crisis. The rest of the paper is structured as follows. Section II deals with two alternative explanations of financial crises, the credit boom-and-bust and the monetarist explanations. Each of these two hypotheses can be supplemented by or set in an asymmetric information framework. The boosted (by asymmetric information) credit boom-and-bust explanation has a broader reach than the boosted monetarist explanation, especially in a world where bank runs have become relatively rare. The ongoing subprime crisis has many features that are consistent with the boosted credit cycle hypothesis. Section III tackles the other two themes of the paper, safety nets and regulation. Safety nets and regulation, the two being largely complementary, grew out of the Great Depression experience. Financial integration has then led to an evolution and expansion of these two policies. The process is still on-going given that international financial integration must co-exist with the dominance of national institutions. Safety nets encourage excessive risk taking, which regulation and supervision are meant to compensate or at least tame. The evidence suggests that regulators and supervisors tend to lag behind in plugging the "loopholes" that emerge from financial innovation and the regulatory avoidance incentives of the financial industry. Part of the explanation may in lie in asymmetries of information and differences in the quality of personnel of the regulated institution and the regulator. Another

\footnotetext{
${ }^{5}$ This is also the evidence emerging from the massive data base on financial crises compiled by Carmen Reinhart and Kenneth Rogoff (2008).
} 
reason may be that regulators identify with the industry they regulate and respond to the pressure from the political world to be lenient during troubled times. The ongoing subprime crisis has seen a further expansion of the safety net from banking to finance, where illiquidity has been transferred. Section IV draws the main conclusions of the paper and outlines a few ideas for possible policy reforms based on what we have learned so far from the subprime crisis.

\section{ALTERNATIVE EXPLANATIONS OF FINANCIAL CRISES}

In this section I will first explore two alternative macro explanations of financial crises, then the extent to which a framework of information asymmetry can enrich these hypotheses, and finally extract some lessons from the subprime crisis.

\section{Credit cycle vs. monetary explanations of financial crises.}

There is a long tradition in economics of associating financial crises with credit booms and busts that give rise to booms and busts in securities markets. Three representative authors of this theory are Wesley Mitchell (1913), Irving Fisher (1933), and Hyman Minsky (1977). Charles Kindleberger's (1978) highly cited book on Manias, Panics and Crashes follows in this tradition. A crisis starts with a macro shock or displacement that alters the profit outlook in the economy. To this follows an expansion of bank credit that feeds the economic boom. Firms expand debt relative to equities to finance new projects based on optimistic assessments of future profits. In the words of Fisher (p. 341), “...over-investment and over-speculation are often important; but they would have far less serious results were they not conducted with borrowed money.” Optimism about the future drives the process of capital and debt accumulation. Monetary expansion comes with or promotes the expansion of bank credit. Prices of specific assets increase which leads to a state of euphoria or mania.

Herding behavior is an integral part of manias or fads.

Then, an event occurs that precipitates a reversal and wakes up investors that assets are badly overpriced. This event could be an increase in uncertainty due to political turmoil; a negative shock due to a stock market crash; or an increase in interest rates brought about by monetary authorities who want to put a 
stop to rising inflation. The disturbance deteriorates business outlook. Higher interest rates reduce what Minsky calls the "margin of safety," the excess of assets over liabilities or the excess of positive cash flows over negative cash flows. The future appears dark and anticipated profits decline. Asset prices implode as speculators unload risky assets. ${ }^{6}$ The interaction between profits and speculation sets up a vicious circle that drives up interest rates and leads to a rush for liquidity. In the panic phase of debt liquidation, inflation falls below expectations. Disinflation forces a rise in the real value of debt and debtors suffer a decline in net worth. Business contraction occurs through debt deflation (Fisher, p. 342-3; Taylor and O’Connell 1985, pp. 881-882). Even in the absence of disinflation, the same mechanism is operative through a decline in asset prices that reduces the value of collateral and forces borrowers to put up more security for a given nominal value of debt.

Tobias Adrian and Hyun Song Shin (2008) provide a modern version of this mechanism for those financial intermediaries who mark to market their assets. The argument of these authors goes as follows. Given the balance sheet identity $\mathrm{A}=\mathrm{D}+\mathrm{E}$, where $\mathrm{A}=$ value of assets, $\mathrm{D}=$ value of debt and $\mathrm{E}=$ value of equity, if A is marked to market and D is relatively fixed, any change in A is reflected in changes in E. This implies that the slope of leverage, $\mathrm{L}=\mathrm{A} / \mathrm{E}=\mathrm{A} /(\mathrm{A}-\mathrm{D})$, with respect to $\mathrm{A}$ is negative for a given $\mathrm{D}$. Indeed, for U.S. households there is an inverse empirical correlation between the growth of A and the growth of L. But such a correlation becomes positive for U.S. security dealers and brokers who must mark to market their assets; see the authors' Figure 2.5. One way to rationalize this outcome is to assume that such intermediaries target their leverage levels. In this case, as A increases, D must also increase to preserve the desired leverage value. The testable consequence is that asset prices are positively correlated to debt, a correlation that becomes even stronger if leverage tends to behave procyclically.

In their Monetary History of the United States, Milton Friedman and Anna Schwartz (1963) attribute banking crises to an increase in the public's preference for currency relative to bank deposits, in turn leading to a

${ }^{6}$ In the words of Minsky (1982, p. 42), “[a] recursive process is readily triggered in which a financial market failure leads to a fall in investment which leads to a fall in profits which leads to financial failures, further declines in investment, profits, additional failure, etc." 
contraction of the money stock. To make their point, these authors (see page 167) compare the banking crisis of 1907 with that of 1929-1933 in the United States. In the first, there were no significant bank closings because banks refused to convert deposits into cash. In the second, instead, massive currency withdrawals led to a complete shutdown of the banking system. The difference between the two episodes is in the effects on the monetary base. This point is further elaborated by Schwartz (1986) who makes the distinction between "real” and "pseudo" financial crises. A real financial crisis is "fuelled by fears that means of payment will be unobtainable at any price and, in a fractional-reserve banking system, leads to a scramble for high-powered money” (p. 11). The public becomes distrustful of banks and converts deposits into currency, which in turn lowers the money multiplier and the money stock. Deprived of liquid funding, banks are forced to liquidate their non-marketable assets. Asset prices fall and interest rates rise. Bank insolvencies rise, further heightening the public's mistrust in the banking system. Banking crises, if left to their own devices, thus spill over into wider financial crises (Canova 1994, p. 107). The appropriate response for the monetary authorities is to inject sufficient monetary base to meet the exceptional demand for liquidity and prevent an incipient banking crisis from growing and possibly spreading to a broad range of financial assets. A pseudo financial crisis, on the other hand, involves a fall in asset prices without a concomitant rush for the monetary base. In sum, the monetarist approach predicts that a crisis affects the economy through a reduction of money growth. The credit-boom-andbust explanation, in contrast, sees financial crises impacting the economy independently of money stock effects, for example though asset price changes. Furthermore, the monetarist approach predicts that crises are transmitted under fixed exchange rates through gold and foreign exchange flows. The credit hypothesis, in contrast, sees the transmission mechanism to occur through a variety of channels, including the monetary channel.

Evidence in support of the monetarist explanation of crises relates primarily to the experience of the United States during the National Banking Era (1864-1914) and the inter-war period. Friedman and Schwartz (1963) and Philip Cagan (1965) find that increases in the currency-deposit ratio are a dominant force in the 
cyclical contractions of the money stock, especially those associated with banking panics. ${ }^{7}$ Gary Gorton (1988), studying also the National Banking Era, finds that the currency-deposit ratio rose more during bank panics -such as those of 1873, 1893, 1896, and 1907—than during less severe crises, such as those of 1884 and $1890{ }^{8}$ Gorton also discusses how the creation of the Federal Reserve System in 1914 and the institution of deposit insurance in 1934 altered fundamentally the determinants of the ratio.

At different conclusions arrives Fabio Canova (1994) who studies the predictive power of four theories of financial crises, including the credit cycle and the monetarist, using data from eight U.S. financial crises over a sub-sample (1880 to 1914) of the National Banking Era. ${ }^{9}$ Canova finds that higher short-term interest rates, drop in asset prices, and a sharp decline in excess reserves have some predictive power for the onset of crises; measures of financial market volatility have predictive power in two crises; and currency-deposit ratios have no predictive power. The main conclusion with regard to the monetarist explanation is that " it [is] unlikely that bank runs 'caused' financial crises. Instead, bank runs were probably the endogenous outcome of severe disturbances in financial markets...” (p. 122).

Michael Bordo (1986) assesses the relative explanatory power of the credit and monetarist hypotheses using data from six industrial countries (USA, Britain, Germany, France, Canada and Sweden) on 28 banking and financial crises covering the period 1870-1933. Bordo relies on timing patterns between peaks and troughs of the international business cycles and the chronology of banking and financial crises, and correlation patterns.

7 Elmus Wicker (1996) confirms that during the banking crises of the Great Depression total currency in circulation rose relative to the money stock, variously defined, and that large denomination bills rose relative to total currency, two indicators of the public's distrust in banks. Unlike Friedman and Schwartz in their History, Wicker does not castigate the Fed as inept for failing to counteract the rise in the currency-to-deposit ratio; for Wicker the Fed was simply ignorant at the time of the determinants of the money multiplier (p. 165).

${ }^{8}$ The severity of the crises can be measured by either the duration of loan certificates issued by the New York Clearing House or by the ratio of the quantity of these certificates to deposits issued by the Clearing House banks; see Wicker (2000, Tables 6.3 and 6.4). Either way, the 1884 and the 1890 crises are milder than those of 1873, 1893, 1896, and 1907.

${ }^{9}$ The first theory is driven by seasonal patterns in agriculture and predicts a crisis when the level of excess bank reserves is low or when supply shocks are concomitant with a seasonally high drain of cash. The second theory is the Mitchell-Fisher-Minsky-Kindleberger approach that predicts a crisis when profits are low or the spread between long and short term rates of interest is high. The third theory is the monetarist theory that predicts a crisis when the money stock is declining and the currency-deposit ratio moves up sharply. The fourth theory attributes the crisis to a bubble in the stock market (Wilson et al. 1990) and predicts the onset of the crisis as a result of high volatility in stock returns and in the above-mentioned interest rate spread. 
Severe declines in economic activity are associated with lagged declines in money growth and stock market crises. Yet, Britain, Germany, Canada and Sweden, unlike the United States, did not experience banking panics. ${ }^{10}$ While Bordo favors the monetarist explanation, one of its key implications, namely that banks runs lead to financial crises, is not supported. Bordo attributes the U.S. peculiarity to the fragmented nature of its banking system and to the inconsistent role played by the Clearing Houses and the U.S. Treasury as lenders of last resort (LOLR).

Ben Bernanke and Harold James (1991) focus on the inter-war crises using data from 24 countries. They arrive at two conclusions. The first is that banking panics of this era were the endogenous response to deflation and the mechanism of the gold standard. The second is that panics exert economically large and statistically significant negative consequences on output: a year of panic, on average, is estimated to lower output by 16 percentage points. These findings reinforce those of an earlier and highly cited study on the Great Depression by Bernanke (1983) where he builds on the work by Friedman and Schwartz and identifies the credit channel as an additional source of shocks to the real economy. The work of Bernanke on this topic, singly and with various coauthors, must be seen as treating the credit hypothesis as supplementary to the monetarist hypothesis of crises. When crises erupt, their impact on the real economy can be exacerbated by monetary and credit stringency. To soften the adverse consequences of crises, policy must ensure that not only monetary policy be compensatory but also that credit institutions not withdraw from their vital intermediation role.

\section{$\underline{\text { Asymmetric information and financial crises }}$}

A different approach to understand financial crises relies on the principle and implications that information is not symmetrically distributed across different actors in the economy, namely borrowers know more about their projects than lenders and banks know more about the quality of their loan portfolios than either depositors or regulators. Rather than a separate theory of financial crisis, the asymmetric approach must be seen as supplementary to the theories described above. For Mishkin (1991, p. 70), a leading proponent of the asymmetric information framework, the credit boom-and-bust theory and the monetary theory represent polar

\footnotetext{
${ }^{10}$ France was dropped in the analysis because of lack of data
} 
views of financial crises: the former generates excessively broad implications and justifies an excessive range of government interventions, whereas the monetary theory is instead too narrow and focuses on the role of the central bank as LOLR. The asymmetric information approach modifies and qualifies the positive aspects of both theories; in particular, it expands the reach of the monetarist explanation: “...a decline in the money supply as a result of a financial crisis is not the whole story...it takes a much broader view of what a financial crisis is and puts a very different light on when a financial crisis is real rather than a pseudo crisis.” (p. 75).

A lender that is unable to distinguish a low-risk borrower from a high-risk borrower may charge on loans an interest rate that reflects the average of a risk distribution, as in Akerlof's (1970) lemon problem. Since low-risk customers pay more than they are entitled to, while high-risk customers are subsidized, the pool of customers changes for the worse. Low-risk customers will forego requesting credit and the lender is stuck with the lemons. Lenders can adopt different strategies to counteract adverse selection, such as investing in costly monitoring technology and requesting good collateral as a signal of the quality of the project. In this respect banks, through long-term relationships, have a strong comparative advantage in screening opaque customers, such as small and medium-size enterprises tend to be. Another problem resulting from informational asymmetries is that the borrower may have an incentive to shift the risk profile of her project after she has received the funds. The lower is the equity position of the borrower, the higher is his incentive to shift the burden of additional risks to the creditor. Banks, with good monitoring technology, may pay attention to declines in borrowers' net worth as a potential indicator of changing incentives to risk shifting. A similar problem occurs in the relationship between the bank and a regulator.

A financial crisis manifests itself by widening spreads between interest rates charged on low-quality and high-quality borrowers. This is what Mishkin finds in the U.S. panics of 1857, 1873, 1884, 1890, 1893, 1896, 1907, and of the Great Depression. ${ }^{11}$ The reason is that creditors face mounting difficulty in gathering reliable information on opaque clients. Confronted with a higher degree of uncertainty in assessing the true

\footnotetext{
${ }^{11}$ He also finds them that these panics were preceded by a failure of an important financial institution, occurred during a recession, and were associated with a rise in interest rates and declines in stock prices, findings that are in line with those discussed above.
} 
credit status of relatively opaque borrowers, creditors apply higher interest rates on them. As interest rates rise, asset prices decline. This, in turn, reduces the value of collateral and borrowers' present value of future cash flows. Falling collateral and net worth values accentuate the conflict between lenders and borrowers (agency cost). The creditor feels more at risk because the debtor has now higher incentives to pursue "gambling for resurrection” strategies and has a further reason to raise interest rates. Mounting adverse selection also prompts creditors to ration credit to limit credit risk (Stiglitz and Weiss 1981). Higher interest rates and credit rationing have large effects on investment flows and output because (a) bank credit is very interest elastic and (b) relative opaque borrowers have no substitutes to bank credit. Financial crises can be very costly, a fact that explains why governments are willing to intervene massively in the financial markets and mop up the mess.

Calomiris and Gorton (1991) elaborate further on the information asymmetry approach as it pertains to banking panics. The latter, according to these authors, are an extreme form of monitoring performed by depositors with poor knowledge of the quality of the banks' portfolio of non-marketable loans. The origin of a panic is a disturbance that alters the risk profile of assets rather than a shock to the demand for money. Depositors cannot identify risky banks from safe banks but can impose discipline by converting large amounts of deposits to currency from all banks. The result is that the weaker banks are the first to fail. Of course, safer banks caught in the maelstrom of a panic may fail as well. The authors propose this hypothesis in competition with the random withdrawal hypothesis implied by the Diamond-Dybvig model (1983), which attributes to banks the specific role of transforming non-marketable and illiquid assets into liquid liabilities owned by depositors to smooth consumption.

The two hypotheses emphasize different sides of banks' balance sheet. For the information asymmetry approach, banks are distinctive in that they issue very liquid debt -i.e., par-value deposits-- to finance nonmarketable or illiquid loans to firms whose business plans, governance and accounting are opaque; this is because banks have a comparative advantage in information acquisition and monitoring. Depositors are less informed than the bank about the activities of the customers to whom the banks lend, but have knowledge of the general risk prevailing in the market. When bad news is revealed, depositors cannot do better than rush all banks, cashing deposits from bad and good banks alike. For the random withdrawal hypothesis, banks insure 
against the risk of unanticipated consumption changes. Savings-surplus units use banks to invest in high-yield illiquid assets but, at the same time, like the insurance of tapping liquid assets to sustain unanticipated changes in consumption without incurring losses due to the forced sales of illiquid assets. A coordination failure prevents banks during a panic from allocating available liquid resources among all depositors. The adopted rule is to honor completely the debts of those customers who are early in cashing their deposits, leaving unsatisfied the requests of late depositors. Given this rule, there is an incentive to rush to the bank should a bad news, typically a shock in the demand for money, emerge. Thus, banks can fail even through no fault of their own, i.e. they can be solvent at the time of the shock. Adverse news works differently in the two hypotheses. In the asymmetric information hypothesis, bank runs are triggered by an asset shock, such as a decline in stock prices, reassessment of risk, a jump in business defaults, or fraudulent practices on the part of banks. In the random withdrawal hypothesis, bank runs are triggered by shocks in the demand for money, for example higher cash needs connected with the crop moving season in an agrarian society.

Calomiris and Gorton conclude that the evidence from pre-1913 US panics favors the information asymmetric hypothesis. Two sets of facts are inconsistent with the implications of the random withdrawal hypothesis. The first is that conversions of deposits into currency were not abnormally high in pre-panic periods. When large cash withdrawals harmed the banking system, these withdrawals were accompanied by asset-type disturbances, such as stock price declines (p. 143). The second is that bank failures were not linked to bank runs. Bank failures resulted overwhelmingly from asset depreciation, although asset depreciation is also a prediction of the random withdrawal hypothesis. In the overwhelming number of cases money-market tightness was not responsible for bank failures (p. 154). Wicker (2000), using primary sources, reviews carefully the evidence on the same panics and arrives at a more sober assessment. For example, he differentiates bank closings in suspensions (temporary closings) and receiverships (lasting closings) and finds that approximately one-third of banks suspended as a result of bank runs reopened subsequently, evidence that establishes some connection between bank runs and bank closings (p. 145). Also, in the 1884 disturbance, one-fourth of bank closings emanated from correspondent relationships with the failure of a large bank, evidence that is consistent with the 
random withdrawal hypothesis (p. 145). In sum, the evidence appears to be much more mixed about the relative merit of the two hypotheses.

\section{Lessons from the subprime crisis}

It is useful to start with an essential chronology of the financial crisis of 2007-2008. Early signs of the crisis appeared in February, 2007, when U.S. subprime mortgage specialist lenders Novastar and New Century Financial reported large losses; two months later, New Century filed for Chapter 11 bankruptcy protection; in May, UBS terminated hedge fund Dillon Read Capital Management heavily invested in subprime mortgages; in June, Bear Sterns revealed serious troubles with two of its hedge funds specializing in mortgage-backed securities; in July, insolvent IKB was bailed out by the German banking industry and SachsenLB was sold to Landesbank Baden-Wuerttemberg. Without going into details, the crisis can be characterized as having three phases. The first took place in August of 2007 with interbank lending rates of interest rising sharply above policy rates; other spikes occurred in December of 2007, March and September -October of 2008; see Figure 1.The second involved the collapse of several big financial institutions, starting with Northern Rock in February of 2008; Bear Sterns in June of 2008; and Fannie Mae, Freddie Mac, Lehman Brothers, AIG, Washington Mutual, Bradford and Bingley, and Fortis in September of 2008. The final phase consists of the implosion of equity markets from mid September to October 10 of 2008 and in particular during the "panic" week from the $6^{\text {th }}$ to the $10^{\text {th }}$ of October; see Figure 2.

[Insert Figures 1 and 2 here]

The subprime crisis contains both old and new themes. Among old themes, this crisis, like many others before, finds its roots in a long credit boom and easy money that has fuelled rising asset prices; see BIS (2008, pp. 7-11). Historically low level of policy interest rates and real estate prices rising much faster than goods prices are consistent with a credit-boom-and-bust hypothesis. Figure 1 displays inflation- adjusted Federal funds rates and the growth of U.S. house prices. From November, 2001 - date of the trough of the last recession in the United States-- to July, 2006 -date of the peak of the house price boom according to the Case-Shiller home price 
index —inflation-adjusted Federal funds rates averaged -0.45 per cent, while house prices rose 71 per cent against a rise of the consumer price index (CPI) of 14.3 percent. From July, 2006 to August, 2008 (last available observation of the Case-Shiller index when this paper was written), home prices have declined by 20.3 per cent against a rise of 7.6 per cent of the CPI. While the United States is the country most affected by this crisis, many other countries, especially in Europe, are displaying similar symptoms albeit of lesser intensity.

[Insert Figure 3 here]

The massive net capital flows into the United States for much of the $21^{\text {st }}$ century are another classic feature of a credit boom. ${ }^{12}$ These flows have sustained a domestic absorption way in excess of domestic production. ${ }^{13}$ From 2001 to 2006, the year preceding the crisis, the United States soaked up \$ 3,573 billion of world capital outflows, by far the lion's share; in the peak year 2006, the share rose to 76 per cent (IMF 2008, Table A11). Bernanke (2005) interprets the large U.S. capital inflows as a special phenomenon of the time, resulting from a rightward shift of the saving function in fast-growing Asia and oil-producing economies unmatched by a comparable shift in their investment function. The resulting ex-ante gap between saving and investment has resulted in current-account surpluses and in falling real rates of interest. The developed world, but primarily the United States, has "had" to absorb the capital inflows generated by Asia and oil-producing countries. While it may well be true that the credit boom has been an endogenous response of the savings glut shock, it is apparent that policy in the United States has validated the shock with historically low policy real rates of interest. More likely, the persistence of U.S. external deficits suggests the alternative explanation that the United States enjoys "subsidized” interest rates on its external debt, which permit the country to consume in excess of what it produces (Alessandrini and Fratianni 2008a).

\footnotetext{
${ }^{12}$ As it is documented in Kaminsky and Reinhart (1999), expanding credit and large capital inflows are two important predictors of banking crises in developed countries.

${ }^{13}$ Domestic absorption is defined as the sum of domestic consumption, gross investment and government spending. The ratio of domestic absorption to GDP rose from 1.036 in 2001 to 1.058 in 2006. The ratio of consumption to GDP rose 1.4 percentage points from the period 1998-2002 to the period 2003-2007 (BIS 2008, pp. 28-29).
} 
Every crisis has unique features. Finance is in constant evolution and instruments evolve in response to either technological changes or existing regulation. Bills of exchange were considered both useful and destructive in $18^{\text {th }}$ century England (Hoppit 1986, p. 51). Yet, these bills stood the test of times. 1987 Black Monday in the United States was blamed to computerized trading and equity index futures, both of which have not only survived but prospered. The subprime villain is the "originate and distribute” bank model, whereby banks originate loans or purchase loans from specialized brokers to either sell them in the financial markets or transfer them to a sponsored structured investment vehicle (SIV). The SIV, in turn, packages the loans into collateralized debt obligations (CDO) that may receive a credit risk score by ratings agencies. The SIV, like a bank, performs a maturity transformation. Senior or highly-rated CDOs have a liquidity support from banks in case the SIV is unable to refinance its CDO. The basic aim of the "originate and distribute" model is to spread risk in the marketplace. However, the implementation of the model has created risk-raising counter forces. For one, the originator has reduced incentives in screening debtors when the loans are destined to be placed off balance sheet. ${ }^{14}$ While the origination model is not the product of regulation, regulation has encouraged its use. Regulation or lack thereof, is also responsible for allowing unregulated brokers to perform origination. These brokers have strong incentives to maximize origination fees and little incentive to internalize the long-term adverse consequences of poor credit risk. Finally, the ratings agencies were not up to the task of evaluating these complex and relatively opaque products, often assigning the same letter grade to CDOs and corporate bonds with sharply different default rates. ${ }^{15}$

Another distinctive aspect of the crisis is that even large default rates of subprime mortgages cannot explain the depth of the crisis. Subprime and low-documentation mortgage loans were approximately $\$ 1.5$ trillion at the start of the crisis, representing 20 per cent of the entire mortgage market. In the second quarter of 2007, U.S. households had a net worth of \$ 57.6 trillion, according to the flow-of-funds data compiled by the

\footnotetext{
${ }^{14}$ There is, however, a reputational loss for the institution that performs low-quality screening (Eichengreen 2008, p. 20).

${ }^{15}$ Calomiris (2007, p. 19) quotes from the Bloomberg Market of July, 2007 that CDOs rated Baa by Moody suffered five-year default rates of 24 per cent, whereas corporate bonds with the same rating had default rates of 2.2 per cent.
} 
Federal Reserve. Even assuming a high default rate of 30 per cent on these loans, the size of the expected default would be a paltry three-quarter of one per cent of household wealth. As Adrian and Shin (2008) have pointed out, this is far too small an effect in relation to the severity and duration of the crisis. The big impact of the subprime has occurred through the re-pricing of risk across a variety of assets and the ensuing deleveraging process. In other words, we have seen spillovers across markets and a scramble for liquidity, as envisioned by the credit cycle cum information asymmetry hypothesis.

\section{SAFETY NET AND REGULATION}

Safety net and regulation are opposite sides of the same medal. Governments provide a protective umbrella to the financial industry and at the same times impose on the industry rules of behavior aimed at risk reduction. Banking regulation, such as restrictions on lending and usury laws, goes back a long time, but has acquired a complex and formal structure after the devastating inter-war crises. And with regulation, pari passu, came an expansive and expanding safety net. The United States, having suffered the worst banking crises, led the movement with a spate of reforms, including the Glass-Steagall Act of 1933 that, not only established the Federal Deposit Insurance Corporation, but also restricted banks to expand geographically and functionally (i.e., by separating commercial banking activity from investment banking activity) and to compete in the deposit market through interest rate. Other countries were either slower in following the U.S. example or took a different tack because they had a different governance and political outlook about the importance of transparency in financial transactions. For example, Fascist Italy, having suffered three waves of industrial and banking crises in the Twenties and early Thirties, opted to protect bank depositors by nationalizing the bulk of the Italian banking system and transforming all banking activities as "public law” activities, in essence making banking the business of the State (Fratianni and Spinelli 2001, pp. 316-321).$^{16}$

16 Marcello De Cecco (1986) emphasizes that the protection of bank deposits was a big issue for the silent Italian majority and that the Fascist regime used the idea of depositors' protection to achieve a massive centralization of banking activities. Francesco Giordano (2007, pp. 39-58) provides an interesting comparison of the Italian and U.S. approaches to depositors' protection. The Italian approach favored opaqueness of 
The Depression-era inspired safety nets and regulation were firmly in place after World War II. The 1980s ushered a more liberal climate of capital flows and a deregulation of deposit and credit markets. Cracks began to show in the regulatory apparatus both at the national and international level. The S\&L crisis of the 1980s became a locus classicus of national regulatory forbearance (Kane 1989). It was followed by an even larger regulatory failure in Japan in the 1990s (Nakaso 2001). Evidence was mounting that the safety net and regulation twins were not delivering quick resolutions of financial cries. The safety nets appeared to be subsidizing risk rather than reducing it, while regulatory agencies were following their own wishful gambles for resurrection strategies.

Globalized financial markets, populated by many countries with undeveloped financial structures, poor regulatory frameworks, inadequate supervision, and a history of cronyism, raised the prospect of the transmission of more frequent local failures to the international financial system. It also made patently clear that lower regulation countries, like Japan, could engage in unfair competition with higher regulation countries (Fratianni and Pattison 2002). The Basel Capital Accord of 1988 (Basel I) was born out of these concerns. It was an accord on minimum capital requirements computed by assigning arbitrary weights to different bank asset categories. The mechanistic weighting structure gave an impetus to banks to place off balance sheets assets whose regulatory capital exceeded economic capital, and vice versa. Furthermore, Basel I ignored other important aspects of risk and gave no role to market discipline. The new Basel II Accord of 2004 (yet to be fully implemented) rectifies many of these deficiencies. ${ }^{17}$

The expansion and internationalization of regulation and supervision has been accompanied by a similar expansion of the safety net. Central banks are now fully committed to provide emergency liquidity when a crisis erupts. Deposit insurance systems have proliferated over the last twenty years. At the end of 2003, 87 countries

government intervention and decision-making centralization, the American transparency of transactions and creation of separate and accountable institutions. Yet, the U.S. Banking Act of 1933 and the Italian Banking Law of 1936 shared, among other things, the aim of separating commercial banking from other types of financial intermediation.

${ }^{17}$ Basel II has three components or pillars: Pillar I dealing with alternative methodologies to calculate minimum capital requirements, Pillar II with official supervision, and Pillar III with information disclosure on capital and risk management.For the complete text of the Accord, see http://www.bis.org/publ/bcbs128.htm. 
had such an arrangement in place (Demirguc-Kunt et al 2007, Table 1). The too-big-to-fail (TBTF) principle was officially enshrined in the United States in September of 1984, in the aftermath of the bailout of the Continental Illinois National Bank in Chicago, when the Comptroller of the Currency testified before Congress that eleven banks in the United States were TBTF. In case of insolvency of the TBTF banks, deposit insurance would cover all their deposits. Judging by the reactions of the stock market, the announcement was perceived to be credible: nine of the 11 banks had positive excessive rates of return over a specified time window around the announcement date, in contrast to negative excess rates of return for listed banks not included in the Comptroller's list (O’Hara and Shaw 1990). ${ }^{18}$ Recent events in the subprime crisis reveal that the TBTF policy applies not only to large banks but also to other large financial intermediaries.

In the remainder of this section, I will examine LOLR, deposit insurance and government rescue interventions, as well as how these mechanisms interact with regulation and official supervision. Like in the previous section, I will draw lessons from the current financial crisis.

\section{The Lender of Last Resort}

Much has changed since Henry Thornton (1802) and Walter Bagehot (1873[1927]) wrote about the doctrine of LOLR. ${ }^{19}$ We have moved to a complete fiduciary regime and the growth of the monetary base now is unconstrained by gold or silver. Furthermore, countries operating under flexible exchange rates do not have to

${ }^{18}$ Excess rates of returns are defined as the difference between the realized rate of return and the return predicted by the one-factor capital asset price model. The TBTF list included Bank of America, Bankers Trust, Chase Manhattan, Chemical Bank, Citibank, Continental Illinois, First Chicago, J.P. Morgan, Manufacturers Hanover Trust, Security Pacific, and Wells Fargo.

${ }^{19}$ Thornton prescribed that the Bank of England, during crises, ought " to act with extraordinary liberality towards those who apply to them for discounts” (p. 116), accept assets against discounts that “...are, generally speaking, so safe, that the security either of goods, or stocks, or land... may be considered as nearly superfluous” (p. 119), and not “... to relieve every distress which the rashness of country banks may bring upon them: the bank, by doing this, might encourage their improvidence...” (p. 121). Bagehot, seventy years later, restated Thornton's prescriptions without mentioning him. Bagehot went further than Thornton on the use of high (penalty) interest rates, partly because he placed larger emphasis than Thornton on the simultaneous occurrence of an external drain, namely a gold outflow, and a domestic drain, namely massive conversions of bank deposits into either Bank of England notes and/or specie by a distrustful public (p. 56).The appropriate cure for what Bagehot called the "two opposite maladies," was to raise the bank rate to stem the external drain and, at the same time, lend freely to compensate the effects of the internal drain. Bagehot blamed the Bank for mishandling the crises of 1825, 1837-9, 1847, and 1857, but gave her full marks for handling that of 1866 (pp. $170-2)$. 
worry about the external drain. As to the domestic drain, it has been virtually eliminated by the widespread adoption of deposit insurance. Yet, we still suffer from liquidity crises in places and forms that Bagehot could not envision because the money market and the financial markets have evolved. At the time Bagehot was writing, liquidity was injected in the system by discounting bills in one-on-one transactions. Today, liquidity is injected primarily through open market operations; the money market then redistributes it among individual banks. Liquidity created through the discount window or standing facility has virtually petered out; the reason is that a bank that borrows from the central bank must pay a penalty rate relative to the policy rate.

Banks lend and borrow in the interbank market without collateral. While credit risks are evaluated and monitored through continued exposure, information asymmetry impedes a lending bank to know exactly the credit status of a borrowing bank. Should some doubt arise about its solvency, a bank may not be able to borrow at the prevailing interbank rate. Should the bank signal a willingness to pay a higher rate, it may fuel further suspicion (adverse selection) about its credit status. The bank, then, has to turn to the central bank's standing facility. But why would a central bank oblige? The classic answer is that if the bank has good collateral it can borrow at a penalty rate. But if she had good collateral, say T-bills, the bank could sell it in the market and obtain liquidity less expensively than through the discount window. The very fact that a bank knocks at the discount window raises an automatic suspicion of insolvency. It is plausible that a central bank, through its supervisory role, knows more than the market and is able to differentiate insolvency from illiquidity. Marvin Goodfriend and Robert King (1988) do not believe that a central bank has superior knowledge and consequently judge that discount-window lending should not be done because it is capital lending and encourages moral hazard behavior. It is instructive, in this respect, a study conducted in 1991 by the U.S. House Banking Committee that finds that 90 per cent of percent of the institutions that had tapped the discount window from 1985 to mid 1991 failed subsequently (Santomero and Hoffman 1998, p. 18). This evidence appears to be consistent with the view that central banks are incapable of differentiating illiquidity from insolvency. But the fact that a central bank cannot distinguish illiquidity from insolvency does not preclude her from extending emergency lending. Since the losses from such lending fall ultimately on government, it is government that “...ultimately will decide how the crisis is handled and who bears 
the losses” (Goodhart 1999, p. 348). One can extend this argument by including situations in which a central bank enjoys private information but for a variety of reasons decides to lend to insolvent banks.

So, what is the role of the discount window when interbank lending is efficient (low cost) and the banking system can rely on a safety net? The modern literature on LOLR stresses the potential coordination failure of interbank markets during times of stress. The fact that bank loans tend to be opaque and that interbank lending is unsecured induces lenders to withdraw on the mere suspicion that the borrower may have assets of poor quality. Even if the borrower's assets are believed to be of good quality a lender may withdraw if he expects other lenders to withdraw (Freixas et al. 2000). Access to a discount window solves the coordination problem by guaranteeing banks that the central bank stands ready to compensate the loss of private deposits with central bank deposits. Another reason for having a discount window is to provide liquidity that banks would use "for the express purpose of refinancing maturing short-term debts of firms suffering from disruption in the short-term debt market” (Calomiris 1994, p. 37). The assumptions underlying this type of mechanism are that the disruption of short-term debt markets like commercial paper creates negative spillovers and that there is a low degree of substitutability between bank loans and other forms of credit.

The history of emergency lending shows a wide spectrum of patterns: pure forms of LOLR with central banks injecting emergency liquidity in the money markets; injection of emergency lending to individual institutions that are solvent but illiquid; a mixture of LOLR and government bailouts of insolvent institutions; central banks acting as crisis managers by either coordinating collective private guarantees of solvent but illiquid institutions or by organizing rescue operations with private funds; and finally complete failures of exercising LOLR.

A pure case of LOLR, consisting of making public announcements to calm the financial markets and channeling emergency liquidity into the money market, occurred in the aftermath of the stock market crash of Monday October 19, 1987 in the United States. A fine example of emergency lending to an institution that is solvent but temporarily illiquid took place on November 21, 1985, when the Bank of New York - a large custodian 
and an important part of the US payment system-experienced computer failure and was unable to execute outgoing cash payments. ${ }^{20}$

A good case study of a mixture of LOLR with government bailouts of insolvent institutions is provided by the Italian banking crisis of 1931-33 that ultimately led to the nationalization of the three largest Italian banks (Fratianni and Spinelli 2004). LOLR activity was organized in such a way to preserve the fiction that the Bank of Italy was adhering to standard Bagehot principles. The problem was that the banks were insolvent and their assets would have not qualified for rediscounts. To get around this difficulty, a special government unit provided funding to the banks in exchange for the banks' illiquid assets, which were then rediscounted at the Bank of Italy. These transactions were very large and sustained over a period of years. In the peak year of 1932, emergency lending amounted to 47 per cent of currency in circulation in Italy. In sum, the Bank of Italy provided the LOLR, but the Treasury was the deep pockets that ultimately made possible the transactions. The rescue policy prevented significant bank failures, bank panics and decline in the money stock. The Italian experience stood in sharp contrast to what was happening in the United States where, over the same period, approximately 40 per cent of the banks failed and the money stock shrunk by about a third (Friedman and Schwartz 1963, Chapter 7). The Fed’s policy in the Great Depression has become a textbook case of LOLR failure. $^{21}$

Finally, on the central bank acting primarily as a crisis manager, the locus classicus is what the Bank of England did at the height of the crisis of 1890, when the venerable Barings Bros \& Co. was collapsing under the weight of heavy investments in Argentine bonds. The Bank, after receiving a report that had found Bearings solvent, invited private parties to subscribe to a fund to guarantee Barings' liabilities. The old Barings was

\footnotetext{
${ }^{20}$ The result was a large accumulation of cash deficits vis-à-vis counterparties. The Bank of New York had to borrow overnight from the Federal Reserve \$23 billion, an enormous sum for the time and many times the value bank's capital, for which it put good collateral worth \$36 billion. The problem was completely resolved in a day, with the Bank of New York paying \$5 million in interest to the Fed (Goodhart and Schoenmaker 1992, p. 436). The latter took no risk because of the large collateral and the knowledge that the Bank of New York was solvent.

${ }^{21}$ However, Wicker (1996) has two partially exculpatory conclusions about the Fed's responsibilities. The first is that the pre-Fed banking crises were centered in the New York money market. The post-Fed crises were regional in nature and did not spread to the New York money market thanks to the actions taken by the Fed. The second is that lack of knowledge about the working of the money multiplier rather than incompetence was responsible for the Fed's failure to compensate for rise of the currency and reserve deposit ratios.
} 
liquidated and a new Barings was launched. Although the crisis was considered to be very serious by contemporary observers, the spillover onto the financial markets was minor (Batchelor 1986, pp. 53-54). The rescue of Long-Term Capital Management (LTCM) in September of 1998 is the modern-day equivalent of Barings. The Federal Reserve Bank of New York convinced LTCM’s major creditors to inject over \$3.5 billion into the hedge fund to avoid a wider collapse in the financial markets; no public funds were involved. At the international level, the Bank for International Settlements (BIS) has achieved some success as crisis manager (Fratianni and Pattison 2001). The BIS has had a long experience in dealing with central banks and in coordinating their financial activities. During the Bretton Woods regime, it routinely arranged and coordinated multi-party swap agreements with central banks. Since then it has coordinated international loans to national central banks.

In the aggregate, the most frequent government intervention revolves around rescuing financial institutions. In a study of 104 failing banks around the world covering the period from the late 1970s to the early 1990s, Charles Goodhart and Dirk Schoenmaker (1992) found that rescue occurred in 70 per cent of the cases; the justification was that failure to do so would have induced significant contagion and/or serious disruption of the financial markets. Real counterfactuals are not available to prove whether the actions of the authorities were in fact justified. Furthermore, genuine LOLR represents a small fraction of total rescue operations. In the same sample, of the 74 cases where only one source of funding was used, 23 did not need external funding, 9 were rescued by other banks, 22 by the deposit insurance fund, 18 by government and only 2 by central banks. Goodhart and Schoenmaker infer from this evidence that central banks do intervene only when there is a small probability of losses, otherwise the resolution of the system problem is passed onto the safety net and the deep pockets of government.

\section{Deposit insurance and regulatory forbearance}

Deposit insurance generates benefits and costs. The benefits are that it (i) protects small and uninformed depositors with low incentives to acquire new information and a strong preference for holding "safe" assets and (ii) prevents the failure of a bank from spreading to healthy institutions. The costs are that it reduces depositors' 
incentives to monitor banks while encouraging equity owners to assume more risk. These costs stem from the difficulty of organizing deposit insurance as a market activity (Bhattacharya and Thakor 1993). Since information is distributed asymmetrically between the insurer and the bank, deposit risk cannot be priced in an actuarially fair way. The consequent mispricing of risk-e.g., a flat-fee insurance premium-- induces moral hazard on the part of the insured who takes more risk because losses are shifted to the insurer, whereas profits are fully internalized. Large banks are more successful than small banks in pursuing this strategy because governments consider them TBTF.

The critical empirical question is whether deposit insurance reduces the likelihood of banking crises. Asli Demirguc-Kunt and Enrica Detragiache (2002) examine this issue by applying a logit probability model to data from 61 countries over the period 1980-1997. These countries experienced 40 "systemic” banking crises. ${ }^{22}$ The crisis dummy is regressed against a variety of deposit insurance characteristics as well as several control variables. The salient results are that the probability of a crisis actually increases when there is an explicit deposit insurance or with an expanded coverage limit or when the insurance is funded, all relationships that are consistent with moral hazard effects. Countries with the highest coverage limits are five times more likely to incur in a crisis than countries with the lowest limits ; see authors’ Table 3. Crisis risk is also sensitive to how the insurance fund is managed. If government manages the fund, a crisis is more likely to erupt, again a result that is consistent with moral hazard effect; see authors' Table 5. Finally, the authors combine the various characteristics of deposit insurance schemes in a moral hazard index, which has a strong and positive impact on crisis risk. ${ }^{23}$ However, the interaction of the index with variables capturing strong institutional and regulatory environment lowers the probability of crisis occurrence. In sum, the adverse effects of deposit insurance more than compensate its beneficial effects. Its overall impact is to raise financial instability, especially in countries with weak institutions and poor regulation and supervision (Demirguc-Kunt and Kane 2002, p. 189).

\footnotetext{
${ }^{22}$ Systemic crises are defined as those crises requiring either emergency measures-- such as bank holidays, deposit freezes, blanket guarantees to depositors or other bank creditors—or large-scale nationalization.

${ }^{23}$ The moral hazard index is the first principal component of coinsurance, coverage, scope of coverage, type of funding, source of funding, management and membership.
} 
Barth et al. (2006, pp. 213-224), after extending the Demirguc-Kunt and Detragiache model, are more pessimistic about the possibility that strong regulation and supervision can undo the cost of generous deposit insurance. In fact, their empirical work fails to detect any positive contribution to banking stability (measured again in terms of crisis risk) exerted by either regulatory restrictions on bank activities, or stringency of regulation or the power of official supervision. Restrictions on bank activities may work against the intended purpose because they impede banks from diversifying their revenues and thus raise earnings volatility; this is especially important in countries with developed financial markets. As to regulation and official supervision, the finding may be at odds with a public interest view of regulation and supervision, but not with a public choice view. The fact that Barth et al. find that the nexus between systemic risk and moral hazard is mitigated in countries where the rule of law and political openness are more important (see their Table 4.6) suggests that regulation and official supervision are most harmful in weak institutional environments.

Another purpose of explicit deposit insurance is to facilitate the adoption of procedures for closing insolvent institutions without undue delays and costs. The evidence, however, is that regulatory forbearance is more the norm than the exception. Two big and relatively recent cases of regulatory forbearance occurred in the United States in the Eighties and in Japan in the Nineties. In his study of the S\&L crisis, Kane (1989, ch. 3) discusses several mistakes made by the Federal Savings and Loan Insurance Corporation (FSLIC), the industry’s main deposit insurer. The most egregious error was to wish for better times, a sort of regulatory gamble for resurrection. FSLIC permitted zombie thrifts to "cover up their weakness and thereby conceal parallel weaknesses in FSLIC reserves” (p. 70). To be sure, FSLIC was only in part to be blamed because it was pressured by politicians to be lenient. The politicians, in turn, were pressured by the zombie thrifts. At the core, the problem lied in a weak principal-agent relationship. The public-taxpayer, the ultimate principal, was an unwary victim of the larger costs associated with delaying the closing of insolvent thrifts. Both the politician, the agent of the public, and the regulator, the agent of the politicians, were aided in their obfuscation strategy by the limitations of an accounting system that ignored the costs of contingent commitments like tax forgiveness and federal guarantees (p. 20). 
A similar script applies to the Japanese crisis of the 1990s. During this "lost decade," regulators and supporting politicians gambled for an unlikely resurrection of the banks and their clients. Japanese banks were encouraged to provide additional loans to money-losing companies, with the knowledge that regulators would not enforce capital adequacy rules. At the same time, by putting on hold the reform of the deposit insurance, "the government allowed even the worst banks to continue to attract financing and support their insolvent borrowers” (Hoshi and Kashyap 2004, p. 9). This dilatory strategy contributed in raising substantially the cost to taxpayers of the crisis, estimated to be at least 20 percent of Japan’s GDP (Hoshi and Kashyap, p. 3).

Going beyond specific case studies, Caprio and Klingebiel (1997) develop and analyze a data base of 87 waves of bank insolvencies in 69 countries over a period of approximately fifteen years. As the sub-title of their paper suggests, bank insolvencies are the result of bad luck, bad banking, and bad policies. Using more detailed information on a sub-sample of 29 episodes that include the most serious insolvencies, the authors refine their analysis and find that the driving forces of these insolvencies could be narrowed down to deficient bank management, poor supervision and regulation, government intervention, and politically inspired bank lending. While it is not surprising that bad luck and bad banking are responsible for insolvencies, it is striking that government policies, aimed at alleviating the effects of negative shocks and imprudent banking, actually work to reinforce them.

One needs to acknowledge that past failures have spurred some learning and useful reforms. Following the S\&L disaster, the United States changed in 1991 its deposit insurance regime with the Federal Deposit Insurance Corporation Improvement Act (FDCIA). The biggest innovation of FDCIA was to strengthen the principal-agent relationship between politicians and regulators by simultaneously reducing the margin of discretion available to the regulator in delaying the closing of undercapitalized institutions and the amount of pressure politicians could bring onto regulators to exercise leniency on troubled institutions (Benston and Kaufman 1997). The twin principles of "prompt corrective actions" and "least-cost resolution" now have tightened the regulators' hands but have also given them a degree of independence from the political domain. The reform of the U.S. deposit insurance seems to have inspired many other countries to follow a similar course of action. According to the 2003 World Bank Survey, more than the half of the respondent countries claim to 
have legal predetermined levels of insolvency that trigger automatic actions (Bart et al 2006, Figure 3.12). It is too early, however, to judge whether the implementation has matched the intention of the laws.

\section{Lessons from the subprime crisis}

It is useful to separate three aspects of how policy has reacted to the crisis. The first is the provision of LOLR, for an unchanged stance of monetary policy. LOLR can be channeled to the market with open market operations or to specific institutions through the discount window. The second is government interventions to rescue insolvent institutions. The final is the response of monetary policy to the crisis. On the first issue, central banks, have reacted promptly and decisively as providers of LOLR. ${ }^{24}$ The subprime crisis exploded in August of 2007 with a liquidity squeeze in the asset-backed security markets and the disappearance of many SIVs, which were either liquidated or repatriated by the sponsoring banks. As banks began hoarding liquidity, strains developed in the interbank market; see Figure 1. For example, on August 8, 2007, the interbank rate in the euro zone spiked to 4.6 per cent against a value of 4 per cent of the policy rate. The following day, the European Central Bank (ECB) injected $€ 95$ billion of liquidity, accepting all requests at the policy rate. The Fed did not implement any emergency steps, but put an unusually large \$24bn into U.S. markets in scheduled open market operations. Other central banks either injected additional liquidity or issued statements of their willingness to do so. Additional injections of monetary base were made by the ECB in the next three working days for an amount approximately half of the Thursday’s intervention. ${ }^{25}$

\footnotetext{
${ }^{24}$ The Bank of England was a notable exception to the LOLR activity, at least initially. In a paper sent to a parliamentary committee on September 12, the Bank’s Governor, Mervyn King (2007, p. 7), stated clearly the dangers of moral hazard. In an ironic twist of events, the day after the parliamentary paper, the Bank of England granted an emergency line of credit to Northern Rock. Depositors, rather being reassured by the news, ran on the bank, the first since the run on and failure of Overend, Guerney and Co. in 1866. The Northern Rock's incident had more to do with regulators and supervisors being caught napping at the switch than a real panic. On September 19, the Bank of England also changed its mind about injecting funds into the three-month money market. Other central banks expanded as well the time horizon of open market operations in response to the liquidity pressure in longer dated deposits.
}

${ }^{25}$ The large injections of liquidity, on the whole, did not have lasting effects on either bank reserves or the monetary base, at least up to March of 2008 (Borio and Nelson 2008, p. 39). 
Yet, spreads of three-month interbank lending rates relative to either policy rates or yields on threemonth Treasury bills have remained exceptionally high. Take, for example, the so-called TED spread, that is the difference between the three-month Libor interest rate and the three-month U.S. Treasury bill. Under ordinary times, TED values are contained within 20 to 30 basis points. At the peak of the Mexican crisis of 1994-95 and the South-East Asian financial crisis of 1997, TED rose to approximately 60 basis points. In the Gulf War and the crisis of Long Term Capital Management, TED peaked at approximately 120 basis points. During the entire subprime crisis, TED has moved to uncharted territory. In the month from September 15 to October 14 of 2008 --13 months after the initial liquidity shock of August, 2007-- TED averaged over 300 basis points and reached an all-time high of 464 points on October 10, 2008, the Friday that ended a historic week of panic selling in the equity markets, see Figures 2 and 4. This is evidence of extremely high and persistent adverse selection that the provision of LOLR could not overcome. The state of diffidence permeating the unsecured interbank market was such to have virtually frozen the interbank market for maturities beyond 24 hours. It could have justified a complete takeover of the interbank market by the monetary authorities; see de Grauwe (2008) and Alessandrini and Fratianni (2008b). ${ }^{26}$

\section{[Insert Figure 4 here]}

The takeover of the interbank market did not materialize. The Fed almost did it on October 7, 2008 when it launched a Commercial Paper Funding Facility aimed at providing a liquidity backstop for commercial paper. Under this facility, the Fed will purchase unsecured and asset-backed commercial paper from eligible issuers until April of 2009. For the rest, central banks opted instead for a strategy of liberalizing access to the discount window. In a series of moves, the Fed (i) reduced the difference between the discount rate and the policy rate, (ii) extended the maturity of lending up to 90 days, (iii) extended the facility to Fed unregulated and unsupervised investment banks and primary dealers, and (iv) expanded the range of assets

${ }^{26}$ A complete takeover of the interbank market by the monetary authorities would have lowered the cost of locating credit risks by virtue of the fact that central banks have retaliatory power that commercial banks do not have. On the other hand, a takeover of the interbank market would have required a guarantee by fiscal authorities against losses that the central bank would have incurred by lending on unsecured terms. 
used for collateral. Under the new facility, the Fed can "lend up to \$200 billion of Treasury securities to primary dealers secured for a term of 28 days (rather than overnight, as in the existing program) by a pledge of other securities, including federal agency debt, federal agency residential-mortgage-backed securities (MBS), and non-agency AAA/Aaa-rated private-label residential MBS."27 The upshot is that the Fed has moved ever closer of becoming a market maker of mortgage-backed securities. Similar changes were announced and implemented by the Bank of England. ${ }^{28}$

The liberalization of collateral requirements and the expansion of the list of counterparties implies an expansion of moral hazard (BIS 2008, p. 73). Yet, it is easy to see that this evolution of the LOLR is the direct result of the fact that liquidity risks have moved from the balance sheets of banks to the financial markets. According to Willem Buiter and Anne Sibert (2007), central banks must now assume a role of Market Maker of Last Resort (MMLR). The traditional LOLR, for these authors, was devised to deal with banks' illiquidity when banks originated their loans and kept them on their books, but does not work in the "originate and distribute" model of transferring illiquidity from banks to markets.

The rescue of several very large non-bank financial institutions in the United States and in Europe -the second issue-reflects the migration of liquidity risk from banks to finance and the rapidly expanding role of government as a MMLR and as a backstop of not only big banking but also big finance. The list of large failed institutions is long. After the merger of Bear Stearns with JPMorgan Chase \& Co., financed with a \$29 billion loan by the Fed of New York, the U.S. government gave an explicit and massive guarantee to the liabilities of Fannie Mae and Freddie Mac that held or guaranteed at the time approximately \$ 5,200 billion of mortgages. AIG, the enormous international insurance company, was bailed out by the US Treasury on September 16, 2008, the day after government support was denied to the venerable Lehman Brothers, which had

\footnotetext{
${ }^{27}$ Board of Governors, Press Release of March 11, 2008; see http://www.federalreserve.gov/newsevents/press/monetary/20080311a.htm
}

${ }^{28}$ On April 20, 2008, the Bank of England announced the creation of a new Special Liquidity Scheme according to which it will swap illiquid residential mortgage-backed securities (MBS) for very liquid Treasury bills. Credit risk of MBS pledged as security for the swap remains with the banks. The amount of pledged MBS will be adjusted according to market conditions. Initially, the Scheme will provide up to $£ 50$ billion of liquidity and may last up three years. In essence, the Bank becomes a market maker of MBS. 
to file for bankruptcy. On September 26, the FDIC closed the activities of Washington Mutual, making it the largest bank failure to date. On September 29, the UK government nationalized Bradford and Bingley, a large UK mortgage lender. On September 30, Fortis received emergency funding from the governments of Belgium, the Netherlands and Luxembourg. On October 5, the German government extended guarantees to Hypo Real Estate Bank as part of a private takeover.

Disjointed and ad-hoc government interventions were met by sharp declines in equity prices worldwide; see Figure 3. Finally, pressed by events, US Treasury Secretary Hank Paulson, with the help of Fed Chairman Ben Bernanke, put together a comprehensive but ill-conceived Trouble Asset Relief Program (TARP) that, after a dramatic turnaround, was approved by the Congress on October 3, 2008. The bill authorized $\$ 700$ billion, spread over three tranches, for the US government to purchase sub-standard illiquid assets. The valuation of such assets was the Achilles' heel of TARP: without a market, the government was likely to either overvalue "toxic" assets, thus penalizing taxpayers, or undervalue them, thus penalizing potential sellers. Fortunately, there was language in the bill for the Treasury to use the alternative of recapitalizing banks. ${ }^{29} \mathrm{~A}$ few days later, the UK government launched a comprehensive financial support program centered on the recapitalization of the banking system. $^{30}$ On October 14, Secretary Paulson changed tack and adopted the UK model. The new

\footnotetext{
${ }^{29}$ Interestingly enough, the recapitalization strategy was employed by the Reconstruction Finance Corporation (1932-1953), a fact that seemed to have been completely ignored by the first version of TARP.
}

30 Actually, there are three parts to the program: provision of liquidity, injection of government funds to recapitalize the banking system, and guarantees on bank debt. Eight banks have been identified for recapitalization: Abbey, Barclays, HBOS, HSBC, Lloyds, Nationwide, Royal Bank of Scotland, and Standard Chartered. These institutions have committed to increase capital by $£ 25$ billion. Government will inject $£ 50$ billion in the form of preference shares and with conditions such as limits on executive compensation, dividend policies and commitment to support lending to small business and home buyers. £250 billion will be made available to eligible institutions guarantee new short and medium term debt issuance. To obtain these guarantees the eligible institutions must raise Tier 1 capital to the level deemed appropriate by government. As to the liquidity, the Bank of England will extend liquidity $£ 200$ billion to the banking system under the Special Liquidity Scheme. 
program was relabeled TARP Capital Purchase Program: it was voluntary and eligible institutions would have one month to decide whether to participate. The Treasury will inject public funds in the form of preferred shares that will pay a cumulative dividend rate of $5 \%$ for the first five years and $9 \%$ subsequently. Furthermore, Treasury will receive warrants to purchase common stocks for an aggregate market price of $15 \%$ of the senior preferred shares; the exercise price of the warrants will be the market price of the common stock at the time of issuance and will be calculated on a 20-trading day trailing average. There will be restrictions on dividend payment and executive salary. Other countries follow the UK lead. In sum, governments have stretched enormously the safety net.

The third policy response has been to adjust monetary policy (and prospectively fiscal policy) to the crisis, the greatest reversal has occurred in the epicenter of the financial turmoil. From pre-crisis to September 2008, policy interest rates have declined 375 basis points in the United States, 50 basis points in the United Kingdom, and 25 basis points in the Euro area, while they have remained unchanged in Japan. Each monetary authority has been weighing the risk of a downward overshoot of asset prices and of a severe recession relative to the risk of rekindling inflationary expectations. At the broadest level of generality, we need to be mindful that there are two strategies in restoring equilibrium between the level of asset prices and the level of goods' and services' prices: either let asset prices decline relative to goods’ prices or let goods' prices rise relative to asset prices. The first strategy reduces future moral hazard but carries potentially large short-run output and employment losses, as well as a risk that an overshoot of asset prices may be accompanied by price level deflation with the attendant consequences on the real value of debt emphasized by Fisher (1933) . The second strategy raises moral hazard and the costs connected with a future disinflationary policy, but reduces short-run output and employment losses. The evidence we have so far suggests that the Fed, among all important central banks, sees more risks in the first strategy than in the second. 


\section{CONCLUSIONS AND THOUGHTS FOR POLICY REFORMS}

I like to emphasize four main conclusions of the paper before moving to a discussion of possible policy reforms. First, history suggests that financial crises are an inherent part of finance capitalism. We have yet to find a way to benefit from financial intermediation without incurring periodic financial crises. These crises are more likely to occur under regimes of open financial markets and fixed exchange rate than under regimes of closed financial markets and flexible exchange rates. Second, while there is no single hypothesis that can best explain all crises, the implications of the credit boom-and-bust hypothesis supplemented with asymmetric information are consistent with the onset and development of many crises. Asset values can overshoot, especially when financial institutions and agents can count on credit to expand their leverage. The relevant testable implication is that asset prices are positively correlated to debt. Information asymmetry provides further insights into the process. Crises erupt with widening spreads on interest rates charged on low-quality borrowers relative to interest rates charged on high-quality borrowers. Creditors, lacking reliable information that may enable them to discriminate among specific borrowers, react by raising interest rates on classes of borrowers. The effects of adverse selection are keenly felt when uncertainty rises. These points can help us to understand the evolution of the subprime financial crisis of 2007-08. Credit has been abundant for a long time before the onset of the crisis and has fuelled asset prices. The Fed is at least culpable for tolerating a long stretch of negative real rates of interest. Like other crises before, this one has had its distinctive features, including the "originate and distribute” model that transfers credit risk and illiquidity risk from the balance sheet of banks to the markets. To the extent that the collateralized products are opaque and difficult to evaluate, the spreading of the risk over a larger set of operators makes it more difficult to identify who has such products. During times of stress in the financial markets, investors become distrustful of all financial intermediaries. Thus, the "originate and distribute” model has created the unintended consequence of raising the overall level of uncertainty.

Third, the subprime crisis highlights the weakness of the dollar-based international monetary system, which permits the center country to run persistent current-account deficits. The United States has been able to accumulate a large net external debt without incurring yet a commensurate country-risk premium. This, in turn, has made it easier for the country to consume way in excess of what it produces. The severity of this financial 
crisis is likely to expose the connection between easy credit, external imbalances, and unsustainable debt. Should the markets price a congruous sovereign-risk premium on U.S. debt, external imbalances would have to be absorbed rapidly and bring about a severe recession in the United States and, through spillovers, in the rest of the world. Finally, the subprime crisis has led to an expansion of the safety net. The terms of access to the standing facility of the central banks have been greatly liberalized, especially in the United States and the United Kingdom: both the maturity of the loan and the list of eligible counterparties have been lengthened, while the range of the eligible collateral has been broadened. The end result is that the Fed and the Bank of England have moved ever closer of becoming market makers of mortgage-backed securities.

The safety net has also expanded as a result of governments bailing out large insolvent non-bank financial intermediaries, such as Bear Sterns, Fannie Mae, Freddie Mac, and AIG. Both types of liberalizations may be the direct consequence of the "originate and distribute” model that transfers illiquidity from banks to markets. The massive enlargement of the safety net will exacerbate moral hazard behavior. Credit risk has been shifted onto governments, which may have to pay in the future a higher risk premium on their debts. Furthermore, as the financial industry consolidates into fewer and bigger institutions, future bailouts will become more costly and in some cases even beyond the means of governments' deep pockets.

As the crisis will unwind, there will be policy proposals aimed at closing the regulatory loopholes that have spurred the excessive risk taking in the subprime. It would behoove legislators and regulators to keep a few basic principles in mind and distinguish country-specific policy reforms from reforms with more general applicability. Among country-specific reforms, I include the "peculiar" structure of the U.S. mortgage market and the massive expansion of the U.S. safety net after the bailout of Fannie Mae and Freddie Mac. Home ownership in America is virtually a symbol of citizenship. The government has pursued this objective by easing access to the mortgage market and by providing a tax subsidy on owned homes. Down payments in mortgage lending are low in the United States by international standards. For loans qualifying for assistance under the Federal Administration Housing, these payments represent 3 per cent or even less of the value of the home, generating an obvious incentive for the owner to default should house prices fall by more than 3 per cent. The Community Reinvestment Act of 1977 gave additional incentives to lenders to extend loans to individuals with 
low income and poor credit histories. The bulk of subprime origination was made by independent, federally unregulated, lenders who applied adjustable interest rates and often so-called teaser rates. While there were also (and predictably) shady practices, such as excluding taxes and interest rates from escrow accounts and prepayment penalties, the critical factor at play is the extremely liberal access to lending the has led banks and mortgage originators to take excessive risk. Policy reforms in the United State must address this point and find a different solution -possibly substituting larger and more explicit government subsidies for tighter standards in the mortgage market-- to reconcile the objective of wide home ownership and a more stable financial system.

The bailout of Fannie Mae and Freddie Mac is also a country-specific issue. These two institutions, partly by original design and partly as an endogenous outcome of their clout, have become so big to dominate the U.S. mortgage market. In other words, the government has watched Fannie Mae and Freddie Mac grow to the status of TBTF, despite repeated warnings that such a development would have had negative long-run consequences on tax-payers. Now, the U.S. government has made an explicit commitment to honor the liabilities of Fannie and Freddie, which amount to half of the U.S. Federal debt and 40 per cent of the U.S. GDP. Furthermore, large chunks of these liabilities are in foreign hands. Regardless of whether Fannie and Freddie will be nationalized, the U.S. government is already in the mortgage market, and in a big way. Private lenders will not be able to compete with the government, at least until the government will divest itself from Fannie and Freddie. Financial institutions, especially large ones, will draw the obvious lesson that raising own capital is not important so long as tax-payers can be relied to provide a back stop. This is true not only in the United States, but in other countries as well. ${ }^{31}$ Given the escalating cost of the current crisis, it is tempting to draw a parallel with the Japanese crisis of the 1990s. Yet, there is a big difference. Japan was a large net foreign creditor;

\footnotetext{
${ }^{31}$ This point is made succinctly well by the editorial of the Financial Times of September 8, 2008: "After the Bear Sterns and GSE rescues, it is hard to escape the conclusion that all large US institutions offer the security of Treasury bonds but with above-Treasury returns. This is no less true in other developed economies, as the rescue of Northern Rock in the UK demonstrated. Who believes that the German or Japanese governments would allow one of their own leading banks to fail?”
} 
America is a massive net foreign debtor. The crisis has the potential to raise the cost of borrowing for the U.S. government and to cause a further deterioration of the international brand name of the dollar.

Moving to reforms of more general applicability, I consider the following three. The first is to strengthen the relationship between the legislator-principal and the regulator-agent. The case of Fannie Mae and Freddie Mac is the latest reminder of the enormous damage that can result from the connection of large institutions, with vast lobbying resources, and the political world. The U.S. Congress first privatized the de-facto duopolists in the secondary market for mortgage securities and then gave them a host of privileges, including an exemption from state tax liabilities, a mild regulatory and supervision umbrella, and a $\$ 2.25$ billion line of credit at the U.S. Treasury that has allowed Fannie and Freddie to borrow with almost the credit status of the U.S. government. According to James Leach (2008), the former chairman of the House Banking and Financial Services Committee and thus a person who experienced directly the lobbying power of Fannie and Freddie, “[t]he legislated perks granted Fannie Mae and Freddie Mac are of a multi-billion dollar yearly magnitude and the regulatory advantages they enjoy magnify the capacity of each to grow. It is no accident that no commercial companies in the past generation have had as muscular a lobbying operation on Capitol Hill.” Regulators and the Fed have been subservient to the political will and their behavior has reinforced the historical record that the costs of resolving financial crises have been aggrandized by weak principal-agent relationships. Regulators, like central banks, would perform better if they were given clear and non-conflicting objectives, made independent of the executive branch of government, and rendered accountable to the principal. Such independence could be made formal by a legislative act that would spell out the objectives of regulation and, at the same time, make the regulators accountable through periodic reporting to Congress, as it is the currently the case with the Fed reporting on monetary policy.

In some countries, but primarily in the United States, the regulatory architecture will have to be simplified with the objective of minimizing the incentives financial intermediaries now have in engaging in regulatory arbitrage. The second is not to regulate out of existence either securitization or the "originate and distribute” model that was meant to diffuse risk in the financial markets. The problems are not with the original design of the innovation but with its implementation. Existing regulatory incentives have encouraged banks to 
unload off balance riskier assets and keep in balance lower risk assets. Basel II will big a large improvement over Basel I in this respect. Ratings agencies are also responsible for the poor implementation of the "originate and distribute" model. These have been allowed to give regulatory-type stamps of approval by assigning letter grades to debt. Return ratings agencies to do what they do best, namely the evaluation of credit risk and the computation of default probabilities and expected losses. As Calomiris (2007, p. 19) puts it, these agencies already sell the software "to investors that permit exactly this sort of analysis.” Leave the business of the stamp of approval to independent and accountable regulators.

The third and final reform is to assign a larger role to market discipline. Basel II recognizes this principle under Pillar III but in practice it is expected to play a minor role. Markets are machines of information gathering and risk evaluation. Let us use them to help regulators in determining the trigger points for "prompt corrective action" with respect to troubled institutions. Several economists have written on the subject. For brevity, I refer to the proposal of the Shadow Financial Regulatory Committee (1999) that would compel banks to issue subordinated debt and give debt holders the incentive to perform the monitoring function and determine the level of risk taken by the issuing bank. The regulators could use the interest rate spread between subordinated and unsubordinated debt as a critical input for implementing promptly corrective actions. Holders of unsubordinated debt would be better in evaluating risk than ratings agencies for the simple fact that they do not suffer from the conflict of interest that instead afflicts the relationship between debt debtors and ratings agencies. Furthermore, unlike ratings agencies, debt holders stand to lose wealth if they make mistakes. 


\section{References}

Alessandrini, Pietro and Michele Fratianni (2008a). Resurrecting Keynes to Stabilize the International Monetary System, Università Politecnica delle Marche.

Alessandrini, Pietro and Michele Fratianni (2008b). Un super-garante per il credito, Il Sole-24 Ore, October 30,

Adrian, Tobias and Hyun Song Shin (2008). Liquidity and Leverage. Federal Reserve Bank of New York. Available at http://www.newyorkfed.org/research/staff reports/sr328.html

Akerlof, George (1970). The Market for Lemons: Quantitative Uncertainty and the Market Mechanism, Quarterly Journal of Economics 84: 488-500.

Allen, Franklin and Douglas Gale (2007. Understanding Financial Crises. Oxford: Oxford University Press.

Bagehot, Walter. (1873). Lombard Street: A Description of the Money Market. London: H.S. King.

Bank for International Settlements (2008). $78^{\text {th }}$ Annual Report. Basle.

Barth , James R., Caprio, Gerard Jr. and Ross Levine (2006). Rethinnking Bank Regulation: Till Angels Govern. Cambridge: Cambridge University Press.

Benston, George J. and George G. Kaufman (1997). FDICIA After Five Years, Journal of Economic Perspectives 11(3):139-158.

Bhattacharya Sudipto and Anjan V. Thakor (1993). Contemporary Banking Theory, Journal of Financial Intermediation 3:2-50.

Bernanke, Ben (1983). Nonmonetary Effects of the Financial Crisis in the Propagation of the Great Depression, American Economic Review 73(3): 257-276.

Bernanke, Ben S. (2005). The Global Saving Glut and the U.S. Current Account Deficit, speech delivered for the Sandridge Lecture at the Virginia Association of Economists, Richmond, March 10; available at www.federalreserve.gov/boarddocs/speeches/2005/200503102/default.htm.

Bernanke, Ben and Harold James (1991). The Gold Standard, Deflation, and Financial Crisis in the Great Depression: An International Comparison. In R. Glenn Hubbard (ed.), Financial Markets and Financial Crises. Chicago: The University of Chicago Press.

Bordo, Michael (1986). Financial Crises, Banking Crises, Stock Market Crashes and the Money Supply: Some International Evidence, 1870-1933. In Forrest Capie and Geoffrey E. Wood (eds.), Financial Crises and the World Banking System. New York: St. Martin's Press.

Bordo, Michael, Barry Eichengreen, Daniela Klingebiel and Maria Soledad-Peria (2001). Is the Crisis Problem Growing More Severe? Economic Policy 16 (April): 51-82. An extended version of the paper is available through the Web.

Borio, Claudio and William Nelson (2008). Monetary Operations and the Financial Turmoil, BIS Quarterly Review, March: 31-46.

Buiter, Willem and Anne Sibert (2007) The Centrak Bank as the Market Maker of Last Resort: From Lender of Last Resort to Market Maker of Last Resort, available at http://www.voxeu.org/index.php?q=node/459.

Cagan, Philip (1965). Determinants and Effects of Changes in the Stock of Money, 1875-1960. New York: Columbia University Press.

Calomiris, Charles W. (1994). Is the Discount Window Necessary? A Penn Central Perspective, Federal Reserve Bank of St. Louis Review , June: 31-55.

Calomiris, Charles W. (2007). Not (Yet) a 'Minsky’ Moment. Unpublished paper (October 5).

Calomiris, Charles W. and Gary Gorton (1991). The Origins of Banking Panics: Models, Facts, and Bank Regulation. In R. Glenn Hubbard (ed.), Financial Markets and Financial Crises. Chicago: The University of Chicago Press.

Canova, Fabio (1994). Were Financial Crises Predictable?, Journal of Money, Credit and Banking, 26(1): 102-124. 
Caprio,Gerard, Jr. and Daniela Glingebiel (1997). Bank Insolvency: Bad Luck, Bad Policy, or Bad Banking? In Michael Bruno and Boris Pleskovic (eds.), Annual Bank Conference on Development Economics 1996. Washington, D.C.: The World Bank.

Cipolla, Carlo M. (1982). The Monetary Policy of Fourteenth-Century Florence. Berkeley, CA.

De Cecco, Marcello (1986). La 'protezione del risparmio' nelle forme finanziarie fascite, Rivista di Storia Economica 3(2): 237-241.

De Grauwe, Paul (2008). Temporary Full State Ownership Is Only Solution, Financial Times, October 9.

Demirguc-Kunt, Asli, and Enrica Detragiache (2002). Does Deposit Insurance Banking System Stability? An Empirical Investigation, Journal of Monetary Economics 49(7): 1373-1406.

Demirguc-Kunt, Asli and Edward J. Kane (2002). Deposit Insurance around the Globe: Where Does it Work?”, The Journal of Economic Perspectives 16 (2): 175-195.

Demirguc-Kunt, Asli, Kane, Edward J. and Luc Laeven (2007). Determinants of Deposit-Insurance Adoption and Design, NBER Working Paper N. 12862 (January).

Diamond, Douglas W and Philip H. Dybvig (1983). Bank Runs, Deposit Insurance and Liquidity. Journal of Political Economy 91: 401-19.

Eichengreen, Barry (2008). Ten Questions about the Subprime Crisis, Financial Stability ReviewSpecial Issue on liquidity 11 (February): 19-28.

Ferguson, Niall (2001). The Cash Nexus: Money and Power in the Modern World. New York: Basic Books. Financial Times (September 8, 2008). The end is nigh for Freddie and Fannie.

Fisher, Irving (1933) The Debt Deflation Theory of Great Depressions, Econometrica Vol 1; 337-57.

Fratianni, Michele and John Pattison (2001). The Bank for International Settlements: An Assessment of its Role in International Monetary and Financial Policy, Open Economies Review, 12:197-222.

Fratianni, Michele and John Pattison (2002). International Financial Architecture and International Financial Standards, Annals, AAPSS (Annals of The American Academy of Political and Social Science), 579, January 2002: 183-199.

Fratianni, Michele and Franco Spinelli (2001). Storia monetaria d'Italia: Lira e politica monetaria dall'Unità all'Unione Europea. Milano: Etas.

Fratianni, Michele and Franco Spinelli (2004). The Strong Lira Policy and Deflation in Italy’s Interwar Period.” In Richard C.K. Burdekin and Pierre L. Siklos (eds.), Deflation: Current and Historical Perspectives, Cambridge University Press, pp. 218-240.

Freixas, Xavier, Parigi, Bruno and Jean-Charles Rochet (2000). Systemic Risk, Inter-bank Relations and Liquidity Provision by the Central Bank, Journal of Money Credit and Banking, 32(2): 611-638.

Friedman, Milton and Anna J. Schwarts (1963). A Monetary History of the United States: 1867-1960. Princeton: Princeton University Press.

Garber, Peter (1971). Famous First Bubbles. Cambridge, Mass: The MIT Press.

Garcia, Lillian (1989). The Lender of Last Resort in the Wake of the Crash, American Economic Review, 79(2):151-155.

Giordano, Francesco (2007). Storia del sistema bancario italiano. Roma: Donzelli.

Goodfriend, Marvin and Robert G. King (1988). Financial Deregulation, Monetary Policy, and Central Banking, Federal Reserve Bank of Richmond Economic Review May/June: 3-22.

Goodhart, Charles (1999). Myths about the Lender of Last Resort, International Finance, 2(3): 339-360.

Goodhart, Charles and Dirk Schoenmaker (1992). Institutional Separation Between Supervisory and Monetary Agencies. Giornale Degli Economisti e Annali di Economia 60 (9-12): 353-439.

Gorton, Gary (1988). Banking Panics and Business Cycles, Oxford Economic Papers, 40: 751-781.

Hoppit, Julian (1986). Financial Crises in Eighteenth-Century England, The Economic History Review, New Series. 39(1): 39-58.

Hoshi, Takeo and Anil K. Kashyap (2004). Japan's Financial Crisis and Economic Stagnation, Journal of Economic Perspectives 18(1): 3-26.

International Monetary Fund (2008). World Economic Outlook (April). Washington, D.C. 
Kaminsky, Graciela and Carmen Reinhart. 1999. The Twin Crisis: Causes of Banking and Balance of Payments Problems. American Economic Review, 89(June): 473-500.

Kane, Edward J. (1981). Accelerating Inflation, Technological Innovation, and the Decreasing Effectiveness of Banking Regulation, . The Journal of Finance 36 (2, May): 355-367.

Kane, Edward J. (1989). The S\&L Insurance Mess: How did it Happen? Washington, D.C.: The Urban Institute Press.

Kindleberger, Charles P. (1978 [2000]). Manias, Panics, and Crashes: A History of Financial Crises, $4^{\text {th }}$ edition, New York: Wiley.

King, Mervyb (2007). Turmoil in Financial Markets: What Can Central Banks Do?, Paper submitted to the Treasury Committee (September 12), http://www.bankofengland.co.uk/publications/other/treasurycommittee/other/paper070912.pdf

Leach, James A. (2008). Fixing Fannie and Freddie: A 'Buy-in' for Taxpayers rather than 'Bail-out for Shareholders, Harvard University, John F. Kennedy School of Government, Institute of Politics, July 16.

Minsky, Hyman (1977). A Theory of Systemic Fragility. in E. J. Altman and A. W. Sametz (eds). Financial Crises: Institutions and Markets in a Fragile Environment. New York. Wiley, 138-52

Mishkin, Frederic S. (1991). Asymmetric Information and Financial Crises: A Historical Perspective. In R. Glenn Hubbard (ed.), Financial Markets and Financial Crises. Chicago: The University of Chicago Press.

Mitchell, Wesley C. (1913). Business Cycles. New York: Burt Franklin.

Mueller, Reinhold. C. (1997). The Venetian Money Market - Banks, Panics, and the Public Debt, 1200-1500. Baltimore: The Johns Hopkins University Press.

Nakaso, Hiroshi (2001). The Financial Crisis in Japan during the 1990s: How the Bank of Japan Responded and the Lessons Learnt. BIS Papers N. 6 (October).

North, Douglass and Barry Weingast (1989). Constitution and Commitment: The Evolution of Institutional Governing Public Choice in Seventeenth-Century England, The Journal of Economic History, 49, 4: 803-832.

O’Hara, Maureen and Wayne Shaw (1990). Deposit Insurance and Wealth Effects: The Value of Being "Too Big to Fail", The Journal of Finance, 45 (5): 587-1600.

Reinhart, Carmen M. and Kenneth S. Rogoff (2008). This Time is Different: A Panoramic View of Eight Centuries of Financial Crises. NBER WP 13882 (March).

Santomero, Anthony M. and Paul Hoffman (1998). Problem Bank Resolution: Evaluating the Options. The Wharton School, Financial Institutions Center, Working Paper 98-05-B.

Schwartz, Anna J. (1986). Real and Pseudo-Financial Crises. In Forrest Capie and Geoffrey E. Wood (eds.), Financial Crises and the World Banking System. New York: St. Martin's Press.

Shadow Financial Regulatory Committee (1999). The Basel's Committee New Capital Adequacy Framework, Statement Number 156, September 27, http://www.aei.org/research/shadow/publications/pageID.241,projectID.15/default.asp.

Stiglitz, Joseph and Andrew Weiss (1981). Credit Rationing in Markets with Imperfect Information. American Economic Review 71: 393-410.

Taylor, Lance and Stephen A. O’Connell (1985). A Minsky’s Crisis. Quarterly Journal of Economics 100: 871-885.

Thornton, Henry (1802). An Inquiry into the Nature and Effects of the Paper Credit of Great Britain. Edited by F.A. Hayek. Fairfield: Augustus M. Kelley.

Usher, A. P. (1943). The Early History of Deposit Banking in Mediterranean Europe. Cambridge, MA: Harvard University Press.

Wicker, Elmus (1996). The Banking Panics of the Great Depression. Cambridge University Press.

Wicker, Elmus (2000). Banking Panics of the Gilded Age. Cambridge University Press.

Wilson, Jack, Richard Sylla, and Charles Jones (1990). Financial Market Volatility, Panics under the National Banking System before 1914, and Volatility in the Long Run 1830-1988. In Eugene White (ed.), Crises and Panics and Historical Perspectives. Homewood: Dow Jones/Irwin. 
Figure 1: Three-month interbank lending rates during the subprime crisis

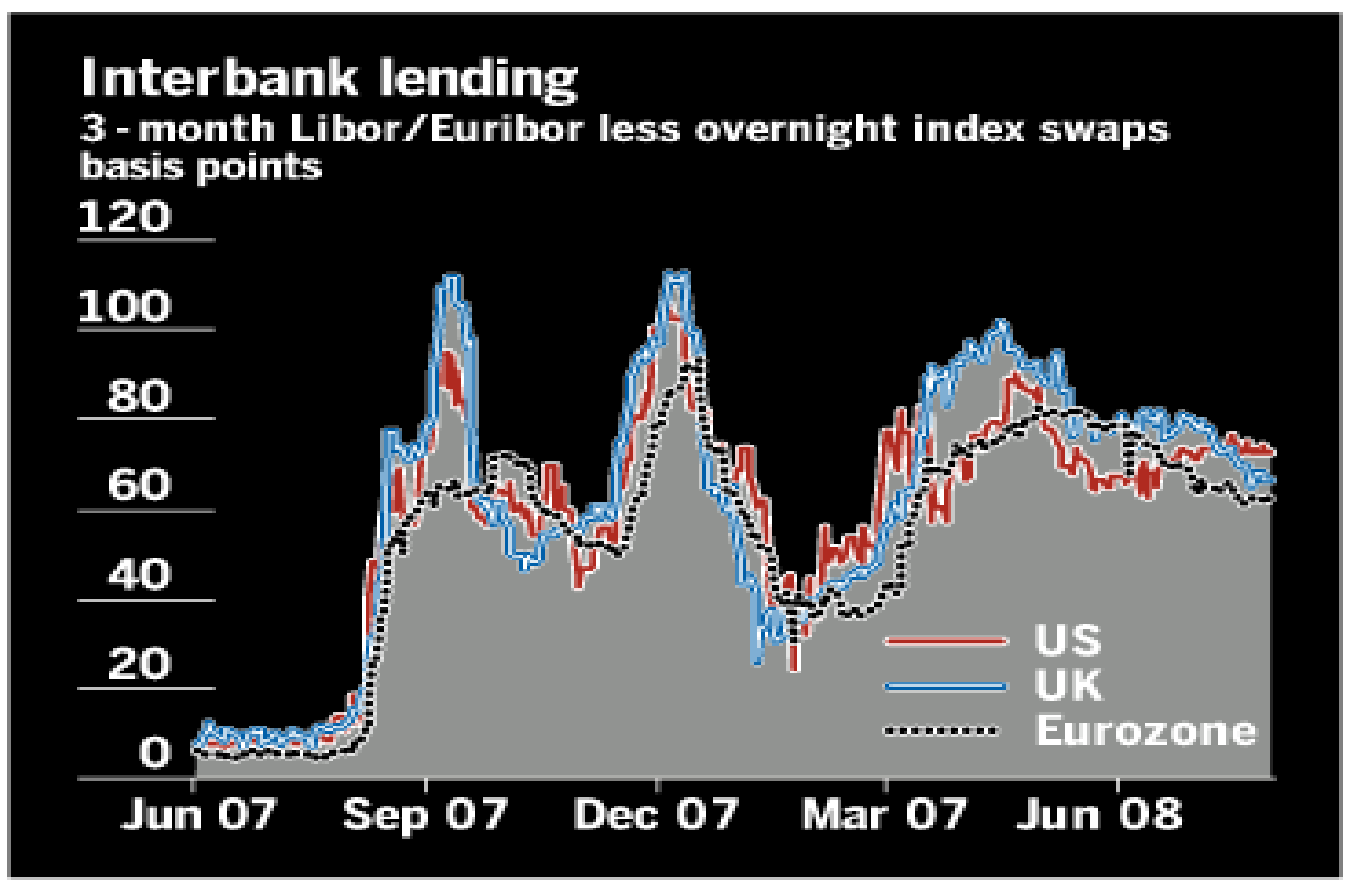

Source: Gillian Tett. Big Freeze part 1: How it began, Financial Times, August 3, 2008. 


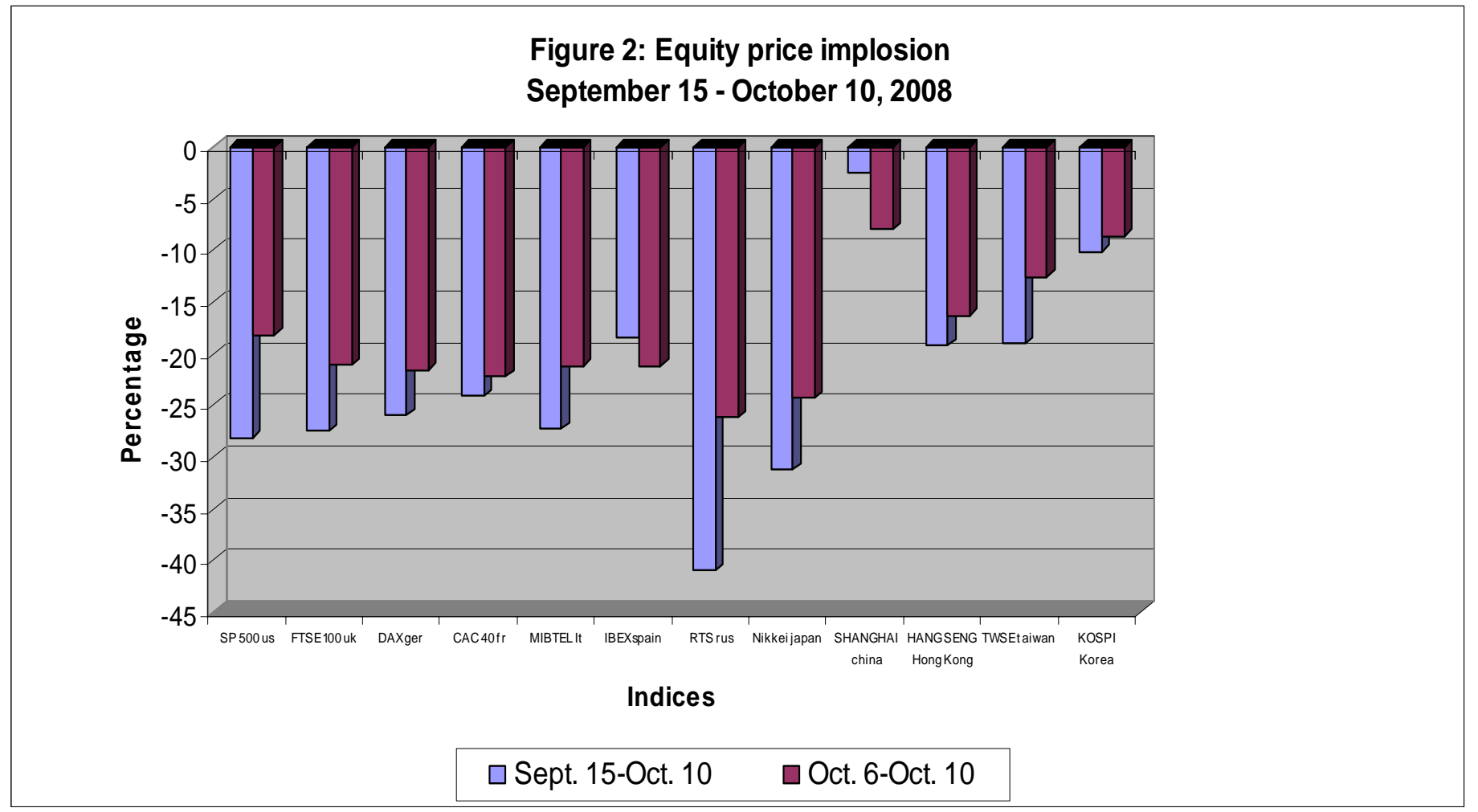

Source: http://www.yahoo.com 
Figure 3: Real interest rates and housing prices in the United States, 2001-August 2008

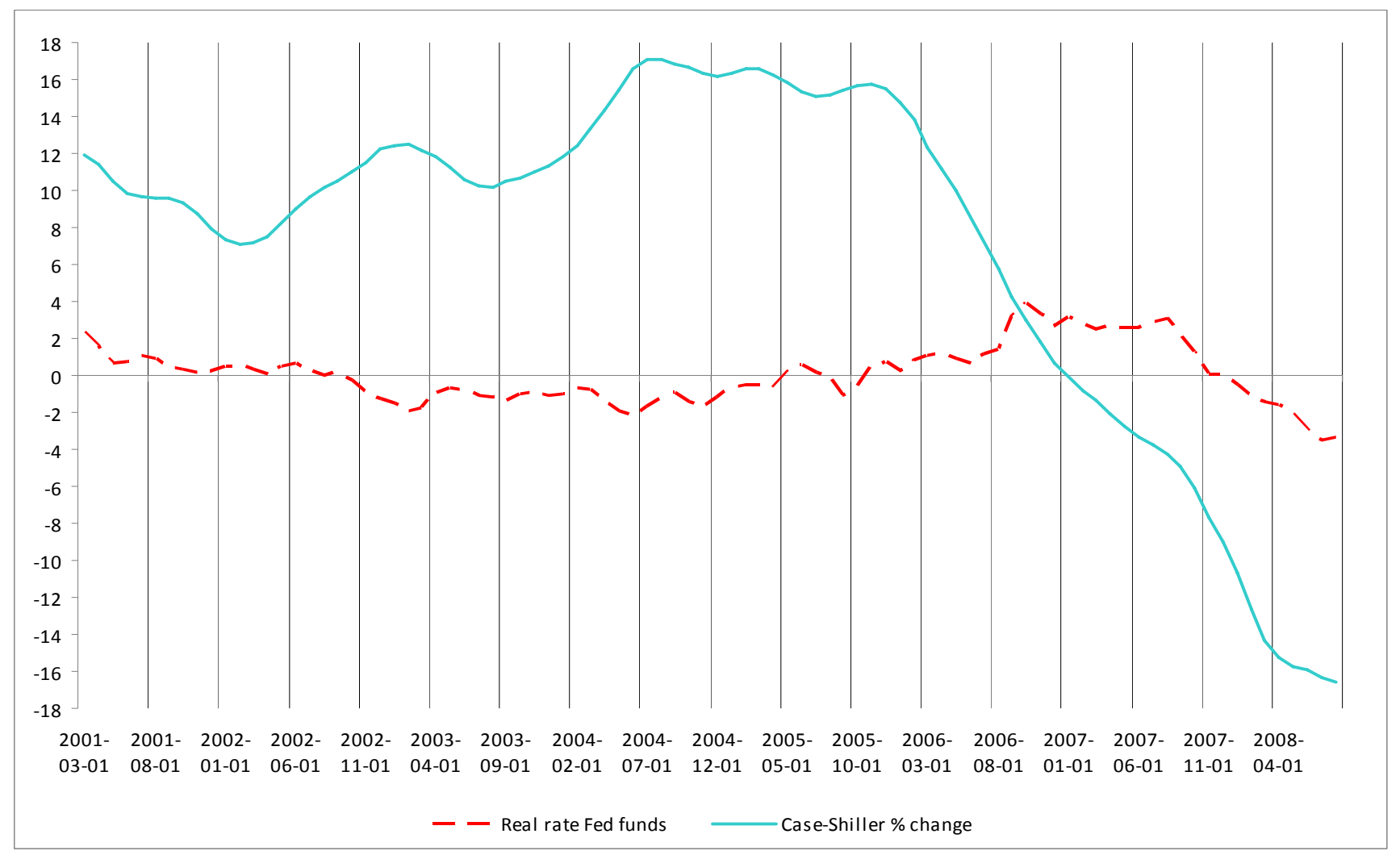

Sources and notes: The Federal funds rate is the money market rate targeted by the Federal Reserve. The inflation adjustment is based on ex-post percentage changes in the consumer price index. U.S. house prices are measured by the 20city composite Case-Shiller home price index;

http://www2.standardandpoors.com/portal/site/sp/en/us/page.topic/indices_csmahp/0,0,0,0,0,0,0,0,0,1,1,0,0,0,0,0.html 


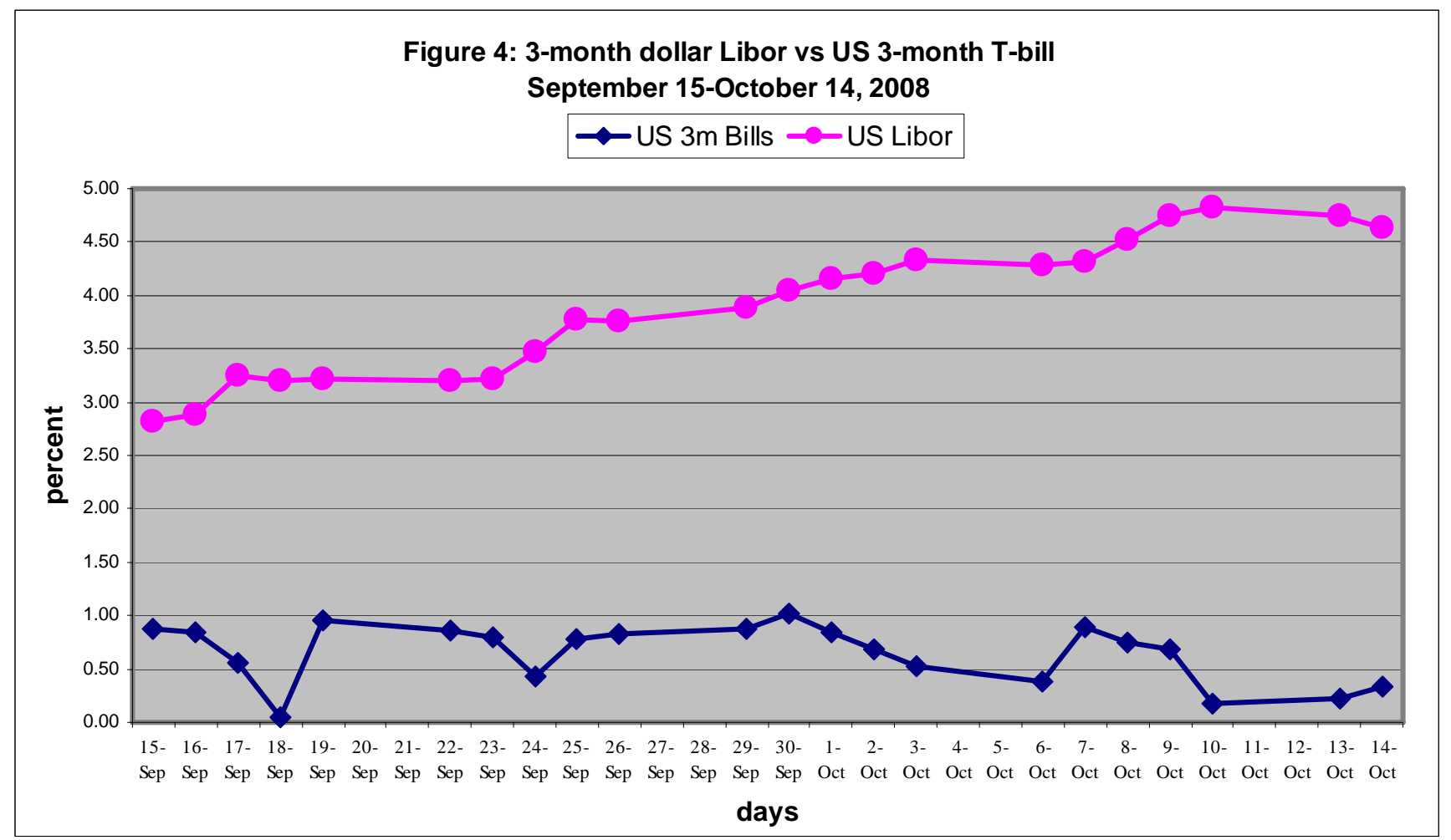




\section{Table 1: Crisis Count (Selected Literature)}

Kingleberger (1978, Appendix B).

Without providing a specific definition, Kindleberger reports 39 major financial cruises over the period 16181997. Many crises group together several countries. Re-arranged by countries (in parentheses the year of crisis eruption), here is the count:

Australia (1893), Austria (1783, 1931), Brazil (1998), Canada (1962), England and later UK (1696, 1720, 1772, 1793, 1797, 1810, 1816, 1818,1825, 1836, 1847, 1857, 1866, 1890, 1921,1931, 1964), France (1720, 1828, 1837, 1857, 1864, 1882, 1958, 1968), Germany (1799, 1848, 1857, 1873, 1907, 1931), Holy Roman Empire (1622), Italy (1866, 1907, 1963), Japan (1931, 1990), Mexico (1982, 1994), Russia (1998), S.E Asia -Indonesia, Korea, Malaysia, Thailand-- (1997), Third World (1982), USA (1792, 1819, 1837, 1857, 1873, 1893, 1907, 1921, 1929, 1933, 1973, 1987).

\section{Bordo (1986, Table 1).}

Bordo lists 36 banking and financial crises for six countries over the period 1870-1933. Banking crises are defined as bank runs and/or failures. Financial crises are those indicated by Kindleberger. Here is the crisis count, arranged by countries (in parentheses the year of the crisis followed by $\mathrm{B}=$ banking crisis or $\mathrm{F}=$ financial crisis):

Canada (1902 F, 1907 F, 1910 F, 1914 B \& F, 1921 F, 1923 B, 1931 F), France (1871 F, 1882 B \& F, 1907 F, 1914 F, 1926 F, 1930 B), Germany (1873 F, 1901 B \& F, 1931 B \& F), Sweden (1907 F, 1914 F, 1931 F, 1932 F), UK (1870 F, 1890 F, 1914 F, 1921 F, 1931 F) US (1873 B \& F, 1884 B, 1890 B, 1893 B \& F, 1907 B \& F, 1914 B \& F, 1921 F, 1929 F, 1930 B, 1931 B, 1933 B).

Bernanke and James (1991, Table 2.7).

Bernanke and James list 42 interwar banking crises, using several criteria including the currency-to-deposit ratio. Here is the crisis count, arranged by countries (in parentheses the year of the crisis):

Argentina (1931, 1934), Austria (1923, 1929, 1931 May and July), Belgium (1931, 1934), Czechoslovakia (1931, 1936), Denmark (1922), Egypt (1931), Estonia (1930, 1931), France (1930, 1931, 1932), Germany (1929, 1931), Hungary (1931), Italy (1927, 1930, 1935), Japan (1927), Latvia (1931), Mexico (1931), Netherlands (1921-22), Norway (1923, 1927, 1936), Poland (1926), Romania (1931 July and October), Spain (1925), Sweden (1921, 1932), Switzerland (1931,1933), Turkey (1931), U.K. (1931), U.S. (1930, 1931, 1932 June and October, 1933).

Bordo et al. (2001, Appendix A).

Bordo et al. identify 240 banking and currency crises for 21 countries for the periods 1880-1913, 1919-1939, 1940-1971, and 1972-1998. They also provide a larger sample of 56 countries for the last period. A banking crisis is defined as "the erosion of most or all aggregate banking system capital" and a currency crisis is defined as "a forced change in parity, abandonment of a pegged exchange rate, or an international rescue." Here is the crisis count based on the 21-country sample and arranged by countries (in parentheses the year of the crisis followed by either $\mathrm{B}=$ banking crisis or $\mathrm{C}=$ currency crisis):

Argentina (1885 C, 1890 B \& C, 1891 B, 1908 C, 1929 C, 1930 C, 1931 B \& C, 1932 C, 1934 B, 1950 C, 1959 C, 1962 C, 1967 C, 1970 , 1975 C, 1980 B, 1982 C, 1984 C, 1985 B, 1987 C, 1989 B \& C, 1991 C, 1995 B \& C) 
Austria (1893 B, 1932 C, 1933 C, 1949 C, 1971 C, 1976 C, 1983 C, 1985 C, 1989 B)

Belgium (1924 C, 1925 B, 1926 B, 1931 B, 1934 B, 1935 C, 1938 C, 1939 B, 1949 C, 1971 C, 1982 C) Brazil (1889 B \& C, 1890 B, 1897 B, 1898 C, 1900 B, 1901 B, 1923 B, 1930 C, 1931 C, 1934 C, 1937 C, 1959 C, 1962 C, 1963 B \& C, 1965 C, 1987 C, 1990 B \& C, 1994 B, 1998 C)

Canada (1891 C, 1893 C, 1908 C, 1921 C, 1923 B, 1929 C, 1931 C, 1950 C, 1962 C, 1962 C, 1981 C, $1986 \mathrm{C})$

Chile (1887 C, 1898 B \& C, 1907 B, 1925 B, 1931 C, 1953 C, 1962 C, 1968 C, 1975 C, 1976 B, 1977 C, 1981 B, 1982 C, 1984 C)

Denmark (1885 B, 1907 B, 1908 B, 1921 B \& C, 1922 C, 1931 B\& C, 1932 C, 1971 C, 1976 C, 1987 B, 1992 C, $1993 \mathrm{C})$

Finland (1900 B, 1921 B \& C, 1931 B \& C, 1939 B, 1949 C, 1971 C, 1986 C, 1991 B \& C, 1993 C)

France (1888 C, 1889 B, 1907 B, 1923 C, 1926 C, 1930 B, 1931 B, 1932 B, 1936 C, 1937 C, 1948 C, 1957 C, 1968 C, 1992 C, 1994 B)

Germany (1893 C, 1901 B, 1907 C, 1931 B \& C, 1934 C, 1949 C, 1977 B)

Greece (1885 C, 1931 B \& C, 1932 C, 1950 C, 1971 C, 1983 C, 1985 C)

Italy (1891 B, 1893 B, 1894 C, 1907 B, 1908 C, 1921 B, 1930 B, 1931 B, 1935 B \& C, 1936 C, 1964 C, 1976 C, 1990 B, 1992 C, 1995 C)

Japan (1990 C, 1901 B, 1904 C, 1907 B, 1908 C, 1921 C, 1927 B, 1931 C, 1932 C, 1979 C, 1992 B)

Netherlands (1897 B, 1921 B \& C, 1923 C, 1935 C, 1939 B, 1949 C, 1971 C, 1992 C)

Norway (1921 B, 1922 B, 1923 B, 1931 B \& C, 1949 C, 1971 C, 1986 C, 1987 B)

Portugal (1891 B \& C, 1920 B, 1923 B, 1931 B \& C, 1932 B, 1971 C, 1976 C, 1978 C, 1983 C)

Spain ( 1920 B, 1924 B, 1925 B, 1931 B \& C, 1958 C, 1967 C, 1971 C, 1976 C, 1977 B, 1982 C, 1992 C, $1995 \mathrm{C})$

Sweden (1897 B, 1907 B, 1931 B \& C, 1932 B \& C, 1949 C, 1971 C, 1991 B, 1992 C)

Switzerland (1931 B, 1933 B, 1936 C, 1939 C, 1971 C, 1977 C)

U.K. (1890 B, 1931 C, 1947 C, 1949 C, 1961 C, 1964 C, 1965 C, 1966 C, 1967 C, 1976 C, 1982 C, $1992 \mathrm{C})$

U.S. (1884 B, 1890 C, 1891 C, 1893 B \& C, 1907 B, 1930 B, 1931 B, 1932 B, 1933 B \& C, 1960 C, 1971 C, 1984 B, 1985 C).

\section{$\underline{\text { Reinhart and Rogoff (2008, Appendix) }}$}

Reinhart and Rogoff have assembled an extremely large data set on financial crises, far too big to be summarized in a table. 